NBER WORKING PAPER SERIES

\title{
THE SMALL WORLD OF INVESTING: BOARD CONNECTIONS AND MUTUAL FUND RETURNS
}

\author{
Lauren Cohen \\ Andrea Frazzini \\ Christopher Malloy \\ Working Paper 13121 \\ http://www.nber.org/papers/w13121
NATIONAL BUREAU OF ECONOMIC RESEARCH
1050 Massachusetts Avenue
Cambridge, MA 02138

May 2007

\begin{abstract}
We would like to thank Malcolm Baker, Nick Barberis, John Campbell, Judy Chevalier, Jennifer Conrad, Kent Daniel, Will Goetzmann, Steve Kaplan, Owen Lamont, Alexander Ljungqvist, Toby Moskowitz, Fiona Scott Morton, Ludovic Phalippou, Bob Shiller, Jeremy Stein, Mike Weisbach, and seminar participants at the University of Chicago, Yale University, London Business School, Harvard University, University of Illinois, Erasmus Universiteit Rotterdam, 2007 Asset Pricing Mini Conference at Washington University, AQR Capital Management, and Goldman Sachs Asset Management for helpful comments. We also thank BoardEx and Linda Cechova for providing firm board data, and Morningstar and Annette Larson for providing mutual fund data. The views expressed herein are those of the author(s) and do not necessarily reflect the views of the National Bureau of Economic Research.

(C) 2007 by Lauren Cohen, Andrea Frazzini, and Christopher Malloy. All rights reserved. Short sections of text, not to exceed two paragraphs, may be quoted without explicit permission provided that full credit, including $\odot$ notice, is given to the source.
\end{abstract}


The Small World of Investing: Board Connections and Mutual Fund Returns

Lauren Cohen, Andrea Frazzini, and Christopher Malloy

NBER Working Paper No. 13121

May 2007

JEL No. G10,G11,G14

\begin{abstract}
$\underline{\text { ABSTRACT }}$ that social networks may be an important mechanism for information flow into asset prices.

Lauren Cohen

Yale School of Management

135 Prospect Street

New Haven, CT 06520

lauren.cohen@yale.edu

Andrea Frazzini

Graduate School of Business

University of Chicago

5807 South Woodlawn Avenue

Chicago, IL 60637

and NBER

andrea.frazzini@chicagogsb.edu

Christopher Malloy

London Business School

Regent's Park

London NW1 4SA

United Kingdom

cmalloy@london.edu
\end{abstract}

This paper uses social networks to identify information transfer in security markets. We focus on connections between mutual fund managers and corporate board members via shared education networks. We find that portfolio managers place larger bets on firms they are connected to through their network, and perform significantly better on these holdings relative to their non-connected holdings. A replicating portfolio of connected stocks outperforms a replicating portfolio of non-connected stocks by up to $8.4 \%$ per year. Returns are concentrated around corporate news announcements, consistent with mutual fund managers gaining an informational advantage through the education networks. Our results suggest 
Information moves security prices. How information disseminates through agents in financial markets and into security prices, though, is not as well understood. We study a particular type of this dissemination in the form of social networks. Social networks are network structures composed of nodes (usually people or institutions) that are connected through various social relationships ranging from casual to close bonds. In the context of information flow, social networks allow a piece of information to flow, often in predictable paths, along the network. Thus, one can test the importance of the social network in disseminating information by testing its predictions on the flow of information. One convenient aspect of social networks is that they have often been formed ex-ante, sometimes years in the past, and their formation is then frequently independent of the information to be transferred. This is the case with the social network we examine. Specifically, we define social networks as those tied to educational institutions. The nodes of our social networks are mutual fund portfolio managers and senior officers of publicly traded companies. We then examine the information flow between these nodes, and test predictions on the portfolio allocations and returns earned by mutual fund managers on securities within and outside their networks.

We believe the two agents of our social network (senior officers and portfolio managers) provide a useful setting because one side likely possesses private information, while the other side has a large incentive to access this private information. Similarly, the stock market is a valuable setting in which to examine private information flow through a social network because of the information's eventual revelation into prices, and so easy relation to stock return predictability. We examine how private information flows from top senior firm officers (and board members) to fund portfolio managers connected through a network.

Our tests focus on educational institutions providing a basis for social networks. Specifically, our goal is to use social networks to study information dissemination in security markets. We use academic institutions attended for both undergraduate and graduate degrees as our network measure and test the hypothesis that mutual fund managers are more likely to place larger bets in firms run by individuals in their network, and earn higher average returns on these 
investments. We motivate the use of educational institutions as a basis for social networks in three ways. First, people often select into undergraduate and graduate programs made up of social groups having aligned interests to their own, generating both a higher level of interaction and a longer relationship length from relationships built. ${ }^{1}$ Second, outside of donations to religious organizations, educational institutions are the largest beneficiary of individuals' charitable donations. Over 1 in 7 dollars donated in 2005 went to educational institutions, suggesting the presence of ties to academic institutions past graduation. ${ }^{2}$ Lastly, there is direct evidence that school relationships are on average more homophilous than those formed in other settings (Flap and Kalmijn (2001)) and that communication between parties is more effective when the two parties are more alike (Bhowmik and Rogers (1971)).

There are a number of potential ways information could be moving through networks. First, there could be a direct transfer from senior firm officers to portfolio managers. Second, the networks could simply lower the cost of gathering information for portfolio managers. So, for instance, it may take fewer calls, or people may be more forthcoming with information if they are inside the network. This explanation would be a case where agents have comparative advantages in collecting certain types of information. Third, it could be that networks may make it cheaper to access information on managers, and so assess managerial quality (for similar reasons as above). We are not able to completely rule out any of these mechanisms, but we do provide evidence of all three working to some extent in the data.

To test whether information is disseminated through education networks, we use trading decisions of mutual fund portfolio managers in firms that have senior officials in their social network (connected firms) and firms that do not (non-connected firms). Grossman and Stiglitz (1976) offer a simple intuition that when agents have comparative advantages in collecting certain types of

\footnotetext{
${ }^{1}$ See Richardson (1940), Lazarsfeld and Merton (1954), McPherson et. al (2001), Fischer et al. (1977).

2 Data from The Giving Institute. In 2005, 15\% of charitable donations ( $\$ 38.6$ billion) were given to educational institutions. The largest recipient, religious organizations, received 36\% (\$93.2 billion) (Giving USA (2006)).
} 
information, we should observe them earning abnormal returns to this information. We attempt to identify exactly these situations where portfolio managers are expected to have a comparative advantage from their respective social networks. We then examine both their portfolio allocation decisions, and ability to predict returns, in both the connected and non-connected classes of stocks.

To better understand our approach, consider the following example. ${ }^{3}$ In March 1996, Mr. Smith was the sole portfolio manager of the Phantom Aggressive Fund, a large cap/blend mutual fund with around $\$ 2.8$ billion under management. Mr. Smith holds an MBA from Harvard Business School (hereafter HBS), class of 1983. According to the March 1996 SEC filing, between September $30^{\text {th }} 1995$ and March $29^{\text {th }} 1996$, Mr. Smith purchased 233,000 shares of Cummins Engine Co. Inc, a large engine maker that he did not previously own. At the quarter's end on March $29^{\text {th }} 1996$, Cummins' shares closed at $\$ 40.365$ bringing the fund total position to $\$ 9.41$ million.

Cummins is an example of a "Harvard Stock": In 1996, 62\% of the board of directors held a degree from Harvard University and $46 \%$ of the board held an MBA from HBS. Over the year after Mr. Smith established a position, a series of good events befell Cummins, pushing up its stock price. In May 1996, Cummins announced a joint venture with the Fiat group to manufacture a new series of diesel engines. Between March 1996 and June 1996 the Phantom Aggressive Fund purchased an additional 105,500 shares. Then, in July 1996 the company announced a joint venture with Dongfeng Motor Corp, China's largest truck producer. 1996 turned out to be a record year for Cummins in terms of sales. Cummins' good fortunes continued into 1997, as in January 1997 Cummins announced that its main machinery was selected for a new class of search and rescue craft designed and manufactured in Italy.

Mr. Smith then unloaded the entire fund's position in Cummins (338,700 shares valued at \$23.9 million) in June 1997. Between March 1996 and June 1997 Cummins' stock price rose by $72 \%$, beating the S\&P500 Index by 36\%. Moreover,

\footnotetext{
${ }^{3}$ This is an actual example from our sample, although we have altered the name of both the portfolio manager and the mutual fund.
} 
the Phantom Aggressive Fund, in addition to earning a large return, unloaded the shares at a market peak: After the liquidation of the entire position by the fund, Cummins' stock performance was poor. Over the subsequent year, Cummins' stock price dropped by $18 \%$, underperforming the S\&P500 Index by $52 \%$. A graphical depiction of the timeline of events is shown in the accompanying Figure 1.

Cummins, however, is not the only Harvard stock in the Phantom Aggressive Fund's portfolio. More generally, between 1993 and 2003 Mr. Smith managed a variety of different funds. Looking at his holdings over time reveals a tendency to place larger bets in companies run by his HBS classmates. Between 1993 and 2003, Mr. Smith's average portfolio weight is only $0.55 \%$, while the average weight on stocks where the company's CEO, CFO, or Chairman holds a Harvard MBA and overlapped with the money manager on the Harvard campus is $2.56 \%$, nearly five times larger.

Not only did Mr. Smith make larger bets on his Harvard-run holdings, but he also received higher average returns on them. Specifically, between 1993 and 2003 Mr. Smith's "connected" investments in companies where a senior officer was also an HBS alumni and overlapped with him, outperformed the "non-connected" portion of his portfolio by $15.1 \%$ a year. His "connected" stock picks also outperformed the S\&P500 Index (15\% per year) and a passive value weighted index of Harvard stocks (12.7\% per year).

In this paper we show that the above example represents in fact a much more systematic pattern, in both holdings and returns, across the entire universe of US mutual fund portfolio managers: fund managers place larger concentrated bets on companies to which they are connected through an education network, and perform significantly better on these connected positions than on non-connected positions.

We create calendar time portfolios that mimic the aggregate portfolio allocation of the mutual fund sector in connected and non-connected securities and show that portfolio managers earn higher returns on their connected holdings. A strategy of buying a mimicking portfolio of connected holdings and selling short a mimicking portfolio of non-connected holdings yields returns up to $8.36 \%$ per year. 
Furthermore, the portfolio of connected stocks held by portfolio managers outperforms the portfolio of connected stocks that managers choose not to hold by $6.32 \%$ per year. Both the portfolio allocation and return predictability results are increasing with the strength of the connection.

We test a number of alternative hypotheses. We include firm characteristics, fund characteristics, and industry, none of which can explain managers' large bets on connected stocks or the abnormal returns managers earn on these connected positions. Another alternative hypothesis is that our findings are driven by the geographical effects documented in Coval and Moskowitz (2001). So, perhaps Michigan students tend to locate around Detroit, while Stanford students tend to locate around Silicon Valley. To test this, we examine fund holdings in local and distant firms and find no differences in our results, suggesting that geographic effects are unlikely to explain our findings. We also show that are results are not driven by a few top schools (ex. Ivy League), or by small fund managers, or by a certain part of our sample period.

We also examine the returns of connected and non-connected stocks around news events. If the high return of connected securities is due to information flow through the network, we would expect to see the bulk of the return premium when the news is eventually released to the investing public. Consistent with this hypothesis, we find that nearly the entire difference in return between stocks within and outside a manager's network is concentrated around corporate news announcements.

We then look at changes in a fund's portfolio manager, and focus on the specific case where the previous manager and the new manager share no educational connection. We find that incoming managers unload securities within the old manager's network, and at the same time purchase securities within their own network. Finally, we show that managers who share a common education network tend to herd with each other in their trading decisions, and do so significantly more on connected stocks within their portfolios.

The remainder of the paper is organized as follows. Section I provides a brief background and literature review. Section II describes the data, while Section III 
explores which schools are most connected to firms and mutual funds. Section IV details the portfolio allocation results. Section $\mathrm{V}$ establishes the main education network return results. Section VI provides robustness checks and considers alternative explanations. Section VII examines portfolio weights around mutual fund manager changes, while Section VIII explores fund manager behavior. Section IX concludes.

\section{Background and literature review}

Our work links a large literature on the portfolio choices and investment performance of mutual fund managers with a growing literature on the role of social networks in economics.

The strand of the mutual fund literature most closely related to our paper is the body of work exploring whether mutual fund managers possess stock-picking ability. The evidence on this question is decidedly mixed. Several papers (Jensen (1968), Malkiel (1995), Gruber (1996), and Carhart (1997)) find that active managers fail to outperform passive benchmark portfolios (even before expenses), while others (Grinblatt and Titman (1989, 1993), Grinblatt, Titman, and Wermers (1995), Daniel et al. (1997), and Wermers (1997)) find that active managers do exhibit some stock-picking skills. ${ }^{4}$ The evidence is similarly mixed as to whether it is possible to identify particular types of mutual funds (or managers) that perform consistently better than others. ${ }^{5}$ Carhart (1997), for example, concludes that most of the persistent performance (net of fees) in the fund industry is a result of managers buying stocks which tend to be high-performing momentum stocks (Jegadeesh and Titman (1993)), with much of the remaining persistence attributable to the worst-performing funds.

Among the very few papers that have been able to successfully link mutual

\footnotetext{
${ }^{4}$ Note that Berk and Green (2004) argue that failing to beat a benchmark does not imply a manager lacks skill.

${ }^{5}$ See Hendricks, Patel, and Zeckhauser (1993), Goetzmann and Ibbottson (1994), Brown and Goetzmann (1994), Gruber (1996), and Elton et al. (1993) for evidence of persistence at various horizons up to 5 years, and Malkiel (1995) and Carhart (1997) for countervailing evidence. See also Cohen, Coval, and Pastor (2005).
}

The Small World of Investing - Page 6 
fund outperformance to measurable characteristics, Chevalier and Ellison (1999) investigate biographical data on managers and find that fund managers from undergraduate institutions with higher average SAT scores earn higher returns. Other evidence from manager-level data indicates that fund managers tend to overweight nearby companies (Coval and Moskowitz (1999), and earn higher returns on their local holdings (Coval and Moskowitz (2001)), suggesting a link between geographic proximity and information transmission. ${ }^{6}$ We add to this list by exploring connections between board members and mutual fund managers, and in doing so identify another channel through which fund managers achieve superior returns.

Directly exploring the role of social networks, connections, and influence in financial markets is a relatively new development in the finance literature. ${ }^{7}$ Closest to our work are the findings in Hong, Kubik, and Stein (2005), who document word-of-mouth effects between same-city mutual fund managers with respect to their portfolio choices, and Kuhnen (2005), who documents a link between past business connections between mutual fund directors and advisory firms and future preferential contracting decisions. ${ }^{8}$ Also related are the findings in Massa and Simonov (2005), documenting a relation between the portfolio choices of individual investors and their past educational backgrounds. ${ }^{9}$

Our empirical strategy is motivated by a network sociology literature (see, for example, Mizruchi (1982, 1992), Useem (1984)) that employs corporate board linkages as a measure of personal networks. Board linkages are typically isolated by looking at direct board interlocks between firms (as in Hallock (1997), "back-door" links among directors across firms (as in Larcker et al. (2005) and Conyon and

\footnotetext{
${ }^{6}$ Chen et al (2005) and Christofferson and Sarkissian (2002) also explore how location affects mutual funds behavior.

${ }^{7}$ See Jackson (2005) for a survey on the economics of social networks.

${ }^{8}$ See also Hong, Kubik, and Stein (2004) for evidence that measures of sociability are linked to increased stock market participation, Hochberg, Ljungqvist, and Lu (2005) for evidence of a positive impact of venture capital networks on investment performance, and Perez-Gonzalez (2006) for evidence of a negative impact of nepotism on firm performance in the context of CEO succession.

${ }^{9}$ See also Parkin (2006), who identifies school clustering of lawyers at law firms that cannot be explained by quality or location, and a link between promotion chances in law firms and the concentration of partners with similar educational backgrounds.
} 
Muldoon (2006)), or direct and indirect links between board members and government agencies or officials (as in Faccio (2006) and Fisman et al. (2006), among others), and have shown to be important mechanisms for the sharing of information and the adoption of common practices across firms. ${ }^{10}$ Our approach is different in that we focus on direct connections between board members and mutual fund managers via shared educational backgrounds.

\section{Data}

The data in this study is collected from several sources. Our data on mutual fund holdings come from the CDA/Spectrum Mutual Funds database, which includes all registered mutual funds filing with the SEC. The data show holdings of individual funds collected via fund prospectuses and SEC N30D filings at either quarterly or semi-annual frequency. We focus the analysis on actively managed US equity funds by including funds with the investment objectives of aggressive growth, growth, or growth and income in the CDA dataset. Additionally, we manually screen all funds and exclude index funds, foreign-based funds, US-based international funds, fixed income funds, real estate funds, precious metal funds, balanced funds, closed-end funds, and variable annuities.

We obtain portfolio managers' biographical information from Morningstar, Inc. For each mutual fund, Morningstar provides the name(s) of the portfolio manager(s), a brief vitae including the manager's starting date as well as previous funds managed, all the undergraduate and graduate degrees received, the year in which the degrees were granted, and the institution granting the degree. Morningstar started collecting the manager's educational background in 1990 . More details on the data collection process are given in the appendix. We match Morningstar's biographical data to the CDA fund holdings using the MFLINKS data link provided by Wharton Research Data Services. Our final mutual fund

${ }^{10}$ Examples of the latter include the adoption of poison pills (Davis (1991)), corporate acquisition activity (Haunschild (1993)), CEO compensation (Khurana (2002)), and the decision to make political contributions (Mizruchi (1992)). 
sample includes survivorship-bias free data on holdings and biographical information for 1,648 US actively managed equity funds and 2,501 portfolio managers between January 1990 and December 2006. This is the base sample of our tests.

Stock return and accounting data is from CRSP/COMPUSTAT. We focus the analysis on common stocks only. ${ }^{11}$ We also collect headlines news from Dow Jones newswires for all CRSP firms between 1990 and 2006. Details of our news database are given in the appendix.

Board of directors and senior company officers' biographical information was provided by BoardEx of Management Diagnostics Limited, a private research company specialized in social network data on company officials of US and European public and private companies. The data contain relational links among board of directors and other officials for active companies. Additionally, Boardex provided us with historical files on inactive companies. Links in the dataset are constructed by cross referencing employment history, educational background and professional qualifications. A typical entry would be as follows: in the year 2001, Mr. Smith, CEO of Unicorn Inc., was "connected" to Mr. White, President of ABC Inc. since between 1992 and 1997 they both served on the board of directors of XYZ Inc, respectively as CFO and COO. The data contain current and past role of every company official with start date (year) and end date (year), a board dummy indicating whether the individual serves (served) on the board of directors in the current (past) employment position, all the undergraduate and graduate degrees received, the year in which the degrees were granted, and the institution granting the degree. Firms are identified by CUSIP number.

For each firm in the sample, we use the historical link files for all individuals to reconstruct the annual time series of identities and educational background of board members and senior officers (defined as CEO, CFO or Chairman). The first entry in our sample is in the year 1939, the last is in 2006. Given the focus of our analysis, we restrict the sample to US publicly traded firms. The social networks we examine in the paper are defined over educational

${ }^{11}$ CRSP share codes 10 and 11.

The Small World of Investing - Page 9 
institutions, and thus we have to link each member of the social network by these institutions. Thus, we match institutions and degrees on Morningstar and Boardex. We group the degrees into 6 categories: (i) business school (MBA), (ii) medical school, (iii) general graduate (MA or MS), (iv) PhD, (v) law school, and (vi) general undergraduate. More details are given in the appendix.

Finally, we match company officials' biographical information to stock return data from CRSP. The final sample includes educational background on 42,269 board members and 14,122 senior officials for 7,660 CRSP stocks between January 1990 and December 2006.

Table I gives summary statistics for the matched samples of firms-boardsfunds from January 1990 - December 2006. From Panel A, we average around 700 funds per year, which comprise $84 \%$ of the mutual fund universe. Our sample of firms averages roughly 4,500 per year, which comprise $96 \%$ of total market value. The number of academic institutions in our sample averages 354 per year. In Panel B we report statistics by firm-year or fund-year. The academic institutions in our sample average 22 senior officers and 6 portfolio managers per institution.

\section{Most connected institutions}

Our data allow us to quantify how "connected" universities are to both publicly traded firms and mutual funds. In Table I, Panel A we list the most connected academic institutions to both firms and mutual funds. Here, a connection to an academic institution is defined as: (i) for firms, any of the senior officers (CEO, CFO, and Chairman) having attended the institution and received a degree, and (ii) for funds, any of the portfolio managers having attended the institution for a degree. Thus, a given firm (fund) can be connected to multiple academic institutions. From Panel A, the most connected university to both publicly traded firms and mutual funds, is Harvard University. Harvard is connected to $12 \%$ of US publicly traded firms. These connections are not merely to mid-level managers, but to senior officers in the firm. Similarly, Harvard is connected to $16 \%$ of active equity mutual funds. University of Pennsylvania, University of Chicago, and Columbia University also consistently appear in the top 
5 most connected schools to both publicly traded firms and mutual funds. It is worth noting that excluding the top connected academic institutions does not affect any of the results in the paper ${ }^{12}$.

The breakdown of the degrees is in Panel B of Table I. Comparing graduate degrees between senior officers and portfolio managers, portfolio managers are more likely to have any post-undergraduate degree, with a higher frequency of MBA degrees. The right side of Panel B in Table I shows the graduation dates of senior officers and of portfolio managers. There is a large overlap in graduation dates between the two groups, occurring in the 1960's and 1970's. The distribution of graduation years suggests that portfolio managers may be on average younger than senior top officers at firms, as the portfolio managers received their degrees later. The significant overlap in years, however, allows us to exploit variation in the networks of those attending the same institution during the same (as opposed to different) years.

\section{Results: Holdings of connected securities}

In this section we examine mutual fund managers' portfolio choices. We compare allocations in stocks to which they are connected within their education network, relative to stocks to which they are not. To begin, we need a metric to define "connected" holdings. We define four types of connections between the portfolio manager and firm, based on whether the portfolio manager and a senior official of the firm (CEO, CFO, or Chairman): attended the same school (CONNECTED1), attended the same school and received the same degree (CONNECTED2), attended the same school at the same time (CONNECTED3), and attended the same school at the same time, and received the same degree (CONNECTED4). ${ }^{13}$ We attempt to define these in increasing degree of strength of the link. We view CONNECTED1 and CONNECTED2 as the weakest connections. For example, individuals that attended the same institutions and/or

\footnotetext{
${ }^{12}$ See the discussion in Section VI and Table IX.

${ }^{13}$ We have also used boards of directors to measure connectedness. We define a board as being connected if at least $50 \%$ of its members have an education connection to the portfolio manager. We report these results in the appendix.
} 
earned the same degree may interact as part of the alumni network. We view CONNECTED3 and CONNECTED4 as the strongest links, providing the highest likelihood of direct social interaction with the connected individual while attending school.

Equity portfolio managers may exhibit preferences for certain securities based on a number of characteristics. Managers may tend to overweight all securities in their network, perhaps due to a form of familiarity bias (see Huberman (2001)), or managers may place large concentrated bets in certain connected securities due to comparative advantages in collecting information through their network. Our focus is on the role of the social network in the transfer of information to security prices, via the trading of actively managed funds. Thus, we look at stocks that managers actively choose to hold and compare the portfolio weights of those inside and outside of the managers' networks. We discuss unconditional overweighting (or the lack of it) in section VIII.

Table III shows OLS pooled regressions of portfolio weights on connected dummies and a series of controls. The dependent variable is the fund's portfolio weight in a given stock, in basis points. The units of observation are stock-fundquarter. All regressions include quarter fixed effects. Controls include \%STYLE, the percentage of the fund's total net assets invested in the style corresponding to the stock in question (the stock's style is calculated as in DGTW (1997)), ME, BM and R12 defined as percentiles of market value of equity, book to market, and past 12 month return. Columns 1 to 4 of Panel A show the basic result: compared to the average weight in a given stock, mutual funds place larger bets on connected securities. Looking at column 1, compared to the average weight of 89.4 basis points, mutual funds invest an additional 28.45 basis points in securities where the firm's senior officials attended the same institution. Moreover, the additional allocation to connected securities is increasing with the strength of the connection: fund managers place an additional 41bp in firms where the senior officer and the portfolio manager overlapped on the school campus (and received the same degree), roughly $44 \%$ higher relative to non-connected stocks. In addition, in other specifications we use industry, firm, fund, and fund investment objective code fixed 
effects. ${ }^{14}$ Although these do explain part of the variation in managers' portfolio choices, all the specifications tell a consistent story: portfolio managers place larger bets in connected securities.

Panel B presents similar tests, although we define the connections slightly differently. In Panel A, CONNECTED1, for instance, measures the cases where the portfolio manager attended the same school as a senior officer of the firm. This will include cases where the senior officer did and did not earn the same degree as the manager, and cases where they did and did not overlap in their time at the school. To isolate the effects of each of these components, we create three non-nested versions of the connection variables. So, in Panel B: CONNECTED1 measures cases where the portfolio manager and senior officer attended the same school, but did not earn the same degree and did not overlap in years; CONNECTED2 measures those cases where the portfolio manager and senior officer attended the same school and earned the same degree, but did not overlap in years; CONNECTED3 measures those cases where the portfolio manager and senior officer overlapped at the school, but did not earn the same degree. From Panel B, all three of these connection proxies result in significantly larger bets on connected stocks. Column 1 shows that simply attending the same school, even with no degree or overlap, is associated with portfolio managers significantly placing larger bets in the connected stocks held. Panel B makes it clear that overlapping of years at the same institution seems to create the strongest tie to an education network: an additional weight of $43 \mathrm{bp}$, or $47 \%$, more than in stocks where the portfolio manager did not overlap with a senior manager at the same university. Including controls and other fixed effects (as in Panel A) leads to similar conclusions. ${ }^{15}$

\footnotetext{
${ }^{14}$ The additional weight is more difficult to interpret with control as now the constant is measured relative to these. In Columns 5-10 we include CONNECTED1 and CONNECTED4 together in each regression. The reason we do not include all connections is that most of our degrees are either an undergraduate or an MBA. This causes CONNECTED1 and 2 to be highly correlated (0.71), as well as CONNECTED3 and 4 (0.70). Thus, we include only one from each pair.

${ }^{15}$ Here we are able to include all connection variables together.
} 


\section{Results: Returns on connected holdings}

\section{A. Portfolio Tests}

The mere fact that fund managers place large bets in connected stocks need not imply that these portfolio choices are beneficial. In this section we explore the performance of fund managers' connected holdings compared to their nonconnected holdings, and test the hypothesis that managers earn higher returns on securities within their network.

We use a standard calendar time portfolio approach. At the beginning of each calendar quarter, we assign stocks in each mutual fund portfolio (based on the most recent SEC filing) to one of two portfolios: connected or non-connected. We use same four types of connections defined in section IV. We compute monthly returns on connected and non-connected holdings between reports, based on the assumption that funds did not change their holdings between reports. Portfolios are rebalanced every calendar quarter and within a given fund portfolio, stocks are weighted by the fund's dollar holdings (i.e., connected stocks are weighted by the fund's dollar holdings in the connected portfolio, and non-connected stocks are weighted by the fund's dollar holdings in the non-connected portfolio). Finally, we compute value weighted calendar time portfolios by averaging across funds, weighting individual fund portfolios by the fund's total net asset value at the end of the previous quarter. This approach has the advantage of corresponding to a simple investment strategy of investing in connected and non-connected securities in proportion to the amount held by the universe of funds.

Table IV illustrates our main result. This table includes all available stocks and all available funds, and focuses on the highest degree of connection (CONNECTED4). We report average annual portfolio returns minus Treasury bill returns (in percent) for the period 1990 to 2006. Table IV indicates that connected holdings earn excess returns of $16.05 \%$ annually on average, compared to $7.81 \%$ for all holdings, and $7.69 \%$ for non-connected holdings. A long-short portfolio that holds the connected portfolio and sells short the non-connected portfolio earns on average $8.36 \%$ per year ( $t$-statistic of 3.78). These high average returns on connected stocks are not accompanied by increased levels of risk. Table IV reveals 
a Sharpe ratio on connected holdings of 0.80 (compared to 0.42 for all holdings, and 0.41 for non-connected holdings); the Sharpe ratio on the long-short portfolio is even higher at 0.92 .

In Table $\mathrm{V}$ we analyze the risk-adjusted returns of our calendar time portfolios. We risk-adjust in two ways: first by calculating characteristically adjusted returns ("DGTW returns") as in Daniel et al (1997), and second by computing five-factor alphas. For each stock, we compute DGTW returns by subtracting the return on a value weighted portfolio of all CRSP firms in the same size, market-book, and one year momentum quintile, from the stock's raw return. The five-factor alpha is the intercept on a regression of monthly portfolio excess returns on the monthly returns from the three Fama and French (1993) factormimicking portfolios, Carhart's (1997) momentum factor and Pastor and Stambaugh's (2003) liquidity factor. Table V reports average annual returns and alphas in percent, for all four degrees of connection (not just the strongest connection as in Table IV).

Table $\mathrm{V}$ indicates that connected holdings outperform non-connected holdings in a statistically and economically significant way for all four degrees of connectedness, and for both methods of risk-adjustment. ${ }^{16}$ Connected holdings earn between $14.76 \%$ and $20.08 \%$ annually in raw returns. The magnitude of the longshort portfolio returns is large, and increases as the strength of the connection increases: the portfolio earns $3.03 \%$ for same school connections (CONNECTED1), $3.71 \%$ for same school/degree connections (CONNECTED2), $6.85 \%$ for same school/year connections (CONNECTED3), and 8.36\% for same school/degree/year connections (CONNECTED4). The corresponding DGTW returns on the longshort portfolio range from $1.69 \%$ to $5.46 \%$ annually, while the 5-factor alphas range from $2.96 \%$ to $8.74 \%$ annually, all of which are statistically significant and economically large. Figure 2 shows annual returns of the calendar time portfolios.

Table $\mathrm{V}$ also reports portfolio returns for the portfolio of connected holdings using the non-nested measures of holdings that do not overlap by year, degree (or

\footnotetext{
${ }^{16}$ For brevity, we do not report results for the equally-weighted calendar time portfolios. These results, which are qualitatively and quantitatively similar to those shown here, are available on request.
} 
both), defined as in Table III. These help to identify the different components driving the return results, and ensure that the returns to each type of connection are not driven solely by high average returns on the CONNECTED4 portfolio (as all measures include all stocks identified by this definition). These non-nested results look similar to those reported using our standard connection measures. The long-short portfolio of connected minus non-connected generates abnormal returns between $1.5 \%$ and $5 \%$. Returns increase with the strength of the connection. However, since most managers and senior officers in our sample hold MBA degrees, requiring a year overlap but no common degree yields very undiversified portfolios; hence for CONNECTED3 we are unable to reject the null of no return predictability.

In addition to examining replicating portfolios of the fund's holdings, we also compute returns on the connected stocks that managers choose not to hold. We are interested in testing the hypothesis that managers have an informational advantage in securities within their network. Since mutual funds are often restricting from short selling, their active portfolio allocation may not reflect their full information advantage. Using the same portfolio construction approach as before, we compute value weighted returns on portfolios of connected securities that managers choose not to hold. For example the "connected not-held portfolio" would consist of a value weighted portfolio of all Stanford stocks that a Stanford manager chooses not to hold in a given quarter. As shown in Table VI, the portfolio of connected stocks held by portfolio managers outperforms the portfolio of connected stocks that managers' choose not to hold by up to $6.32 \%$ per year $(t=3.50)$ for the strongest connection, CONNECTED4.

The results in Table III to Table VI lend support to the hypothesis that fund managers have comparative advantages in gathering information about connected firms. Funds earn higher returns on holdings where the portfolio managers and the firm's senior management have a higher likelihood of social interaction. As a result, a long-short equity portfolio that replicates aggregate funds' holdings in connected and non-connected securities earns large subsequent returns. 


\section{B. Purchases and Sells of Connected Stocks}

In Table VII we investigate trading in connected and non-connected stocks. At the beginning of every calendar quarter stocks purchased within each mutual fund portfolio are assigned to one of two portfolios (connected and non-connected). In this table, "purchases" are defined as first-time purchases of a stock ("pickups") plus all instances where a fund increases its portfolio weight in a given stock relative to its prior position; "sells" are defined as all instances where a fund decreases its portfolio weight in a given stock relative to its prior position, or sells off its entire remaining position in a stock. Table VII indicates that purchases of connected stocks outperform purchases of non-connected stocks by $2.69 \%$ annually $(t$-statistic $=2.27)$ for CONNECTED1, and a striking $9.04 \%$ annually $(t$-statistic $=3.65$ ) for CONNECTED4. Similarly, the DGTW-adjusted long-short portfolio for same CONNECTED4 purchases earns $6.50 \%$ per year, while the corresponding 5factor alpha is $7.01 \%$ annually. Focusing solely on first-time purchases of a stock ("pickups") we find similar results (albeit with less power in some cases): CONNECTED1 pickups outperform non-connected pickups by $4.41 \%$ (DGTW) to $5.03 \%$ (5-factor alpha) per year.

Panel B reports returns subsequent to net sales of connected and nonconnected stocks. If mutual funds correctly anticipated the arrival of negative signals we would expect to see low returns on funds' net sales in connected stocks. Looking at returns on funds' net sales reveals a fundamental asymmetry in their ability to earn high returns on connected firms: a portfolio that is long nonconnected sells and short connected sells actually earns negative abnormal returns. Furthermore, for most of the specifications in panel $\mathrm{B}$ we are unable to reject the hypothesis of no predictability after a fund unwinds a position in connected securities.

These results suggest that although portfolio managers earn high returns on their connected holdings and purchases, the managers are not timing the sells of these positions well. This combined return pattern for purchases and sells is consistent with portfolio managers being more likely to receive (and act upon) 
positive information through the social network. For example, senior firm officers may be more reluctant to disclose negative information about the firm's prospects. Overall, these results indicate that portfolio managers outperform dramatically on their connected purchases (relative to their non-connected purchases), but actually underperform on their connected sells (relative to their non-connected sells), suggesting that fund managers lack timing ability on their connected sells. ${ }^{17}$

\section{Returns around News}

In Table VIII we begin to explore the mechanism behind the high returns earned by portfolio managers on securities within their network. As noted earlier, one way that social networks may benefit fund managers is by facilitating the flow of private information. If the returns to connected stocks are driven by information flow through the network, we would expect to see managers making the bulk of the return premium when the news that was transferred through the network (and so caused the manager to purchase the stock) is eventually incorporated into prices. In order to test this hypothesis, we split the monthly returns for each individual stock into returns on earnings announcements (defined as returns in calendar months with scheduled quarterly earnings releases), returns on "other headlines" (defined as returns in calendar months with at least 1 news announcement on the Dow Jones Newswires, as described in the appendix, but no scheduled earnings announcements), and "no news returns" (defined as returns in calendar months with no news announcements on the Dow Jones newswires and no scheduled quarterly earnings releases). We then compute monthly news returns and no-news returns on connected and non-connected holdings. ${ }^{18}$

In panel $\mathrm{B}$ we report the average return of the long-short portfolio that holds the portfolio of connected stocks and sells short the portfolio of non-connected stocks, and test the null hypothesis that the difference in returns between the connected and the non-connected portfolio on news (no-news) is equal to zero.

${ }^{17}$ See Daniel et al (1997) for evidence that the universe of mutual fund managers lacks timing ability in general.

${ }^{18}$ This decomposition is similar to that in Baker et al. (2005). Focusing on trades (rather than level holdings) prior to earnings announcements, they find that mutual fund managers do seem to exhibit ability in predicting future returns around these earnings announcements. 
Looking at months with no headlines or earnings announcement, we are unable to reject the null hypothesis of no difference between the connected and the nonconnected portfolio. Looking at the return on earnings announcements or other headlines news reveals that the difference in average returns between a portfolio of connected holdings and one of non-connected holdings is entirely concentrated in news months: for all four types of connections, the premium of connected holdings over non-connected is large and significant (ranging from $1.36 \%$ to $4.58 \%$ annually) in months with corporate news announcements and it is not statistically different from zero in months with no headline news.

Panel B also reports similar results for news returns adjusted using a matched sample. Since the release of information moves security prices, it is possible to expect most of the difference in returns between any two portfolios to be concentrated around news release. Thus, the results in panel B may simply reflect the fact that most price movements occur around public announcements. We address this issue using a random control sample. At the beginning of every calendar quarter we sample a random portfolio of 500 stocks from the universe of mutual fund holdings, and compute monthly returns on news and no news. We rebalance the portfolio quarterly to maintain value weights. We bootstrap with replacement 100,000 of such random portfolios. Finally we compute simulationadjusted returns as raw returns minus the average return of random portfolios in the same average return quintile. We then report average (adjusted) return of the long-short portfolio that holds the portfolio of connected stocks and sells short the portfolio of non-connected stocks. Hence we are testing the null hypothesis that the difference in returns between the connected and the non-connected portfolio on news (no-news) is equal to the difference in returns between two random portfolios with the same average return. Results are shown in Panel B. Although adjusting for the average return in news and no news month does reduce the magnitude of the difference in returns, the premium of connected holdings is large and entirely concentrated around news releases. In other words, portfolios of stocks that are located in a fund's education network display a disproportionate amount of (net) positive news (defined as high returns in news months) with respect to a portfolio 
of firms outside the fund's network or a random portfolio with the same average return. Taken together, these results are consistent with the hypothesis that social networks facilitate the flow of private information. The difference in performance between connected and non-connected stocks is disproportionably concentrated at times when information is being released to the investing public in the form of public announcements. In other words, the transfer of information surrounding news releases seems to be a key determinant of the out-performance of connected holdings that we document in the paper.

\section{Robustness Tests}

In Table IX we report a series of robustness checks. The table is split into three panels: Panel A contains tests on sub-periods and firm characteristics, Panel $\mathrm{B}$ contains tests on fund characteristics, and Panel $\mathrm{C}$ contains tests on academic institutions. Panel A indicates that the difference in returns between a portfolio of connected stocks and one of non-connected stocks (hereafter "connection premium") is stronger in small cap stocks (up to $15.72 \%$ annually), although it is still large and reliable for large stocks (up to $8.47 \%$ annually). Thus, it does not seem that small information-opaque firms are driving the results. The connection premium is roughly the same over sub-periods of the sample: 1990-1998 and 19992006. Also, RegFD was passed partway through our sample. Thus, to the extent that the type of information transfer occurring through the networks was covered by RegFD, there may be a difference before and after RegFD was put into effect. Interestingly, the premium is almost identical in the pre- and post-RegFD periods (post-2000Q4), earning up to 9.59\% annually for CONNECTED4 connections compared to $9.75 \%$ annually in the pre-RegFD period. This implies that new laws designed to reduce selective disclosure of information have had no effect on the connection premium we document here. So either the type of information conveyed through these networks is not sensitive to RegFD, or the agents do not perceive a sufficiently large risk of being detected (even if the information transfer is subject to this rule). Last, we control for the effect of geographical proximity on fund returns documented by Coval and Moskowitz (2001). One alternative hypothesis is 
that individuals tend to be employed close to their last academic institution (e.g. Yale graduates tend to operate in firms or funds based in CT), thus generating overlap between academic networks and geographical proximity. To control for proximity, we extract the headquarter location for firms and mutual funds in our sample from their SEC filings on the EDGAR system". We compute "local" ("distant") holdings on connected and non-connected stocks, defined as firms located within (beyond) $100 \mathrm{Km}$ from the fund. Table IX shows that the connection premium is equivalent for both local and distant holdings, suggesting that geographical proximity is unlikely to be driving our results.

Panel B of Table IX shows that the connection premium is also not driven by a given fund investment style. It is robust across various fund manager investment objective codes (ex. Growth compared to Growth and Income), although it is somewhat stronger among large cap funds, particularly for strong connections (CONNECTED4). Interestingly, multi-manager funds earn a higher connection premium than single-manager funds, particularly for strong connections (up to $12.56 \%$ annually for CONNECTED4, compared to $6.71 \%$ for single-manager funds). This could possibly be due to the increased number of education networks these funds have through which to receive information.

Panel C reports tests controlling for different characteristics of the academic institutions. Our results do not appear to be driven by a few top schools; as we split the sample into Ivy League and non-Ivy League schools, the connection premium is roughly equivalent (if anything, it is smaller for Ivy League schools for the highest degrees of connection). Another possibility is that only schools with very large education networks (many firms and portfolio managers) are able to realize returns to the education social network. To test this, we split the sample into the five most connected schools (from Table II), and the rest of the sample. The connection premium is almost identical between the two sub-samples, suggesting that our results are not driven solely by the most connected schools.

\footnotetext{
${ }^{19}$ We use all the 10-K forms (firms) and NSAR forms (mutual funds) on the Edgar system from 1993 to 2006 . We match zip codes to their corresponding latitude and longitude and compute the distance between each fund and its holdings using the following

approximation: distance $=\sqrt{[69.1 \text { (latitude1-latitude })]^{2}+\left[53(\text { longitude1-longitude2) }]^{2}\right.}$.
} 
Lastly, we test the hypothesis of a common school effect using a different measure than Table VI. We create "school-adjusted returns" for each stock, which is the stock's return minus a value-weighted portfolio of all stocks that have senior officers that received at least one degree from the same institution as a senior officer from the given firm. Similar to the connected not-held results in Table VII, the school-adjusted return results indicate that even after this adjustment, portfolio managers' choices of connected firms significantly outperform those connected firms the portfolio manager chooses not to hold.

\section{Manager Changes}

This section examines changes in a fund's portfolio manager. We use manager replacements as a convenient lab to study how changes in the available network influence a fund's portfolio allocation. If the effect we find in Sections IVVI is indeed driven by school connections, we expect to see incoming managers replacing stocks in the previous manager's network with securities within his own network. We follow a standard event-study methodology. In order to obtain a clean measure of changes in the available network, we restrict the analysis to funds managed by a single portfolio manager (not a team) and to manager changes where the new portfolio manager and the prior portfolio manager did not receive a degree from the same academic institution (e.g. a Yale manager replaced by a Stanford manager).

Figure 3 shows changes in portfolio allocation. We measure the changes in holdings in event time from the date of the manager change. Period -1 represents the last portfolio snapshot of the old manager and Period +1 represents the first portfolio snapshot of the new manager. Weight is defined as the percentage holding of a stock averaged over the last 2 quarters (for event quarter $<0$ ) or over the next 2 quarters (for event quarter $>0$ ). ${ }^{20}$ The red line in the figure shows the fund's portfolio weights of stocks connected to the old manager (which are by definition not connected to the new manager). The blue line shows the weights in stocks connected to the new manager (again by definition not connected to the old

\footnotetext{
${ }^{20}$ We average across consecutive quarters since funds' holdings are either quarterly or semi-annual.
} 
manager). Consistent with school connections having an impact on managers' portfolio choices, the incoming manager significantly decreases exposure to firms connected to the previous manager, while at the same time significantly increasing exposure to firms in her network. Both the new manager's drop in portfolio weight in stocks connected to the old manager (-24.73 basis points, t-statistics $=-3.17)$, and the increase in weight in stocks in her network (59.95 basis points, tstatistics $=5.25)$ are economically large, given the average weight in our sample of 89 basis points.

Table $\mathrm{X}$ presents a more formal analysis using a regression approach. An alternative explanation of the findings in figure 3 is that a new manager unconditionally unwinds all positions of the old manager (and replaces them with new ones). A regression approach allows us to control for this effect as well as other determinants of portfolio choices at the stock and fund level. We regress changes in portfolio weights on a series of dummy variables and control variables. The dependent variable is the average fund portfolio weight in the stock in the year following manager change, minus the average fund holding in the year before manager change. The independent variables include a series of dummies and controls. New Manager's Stock (New Manager's Connected Stock) is a categorical variable equal to 1 for any (connected) stock held in the new manager's portfolio. Old Manager's Stock and Old Manager's Connected Stock are defined equivalently. By definition New Manager's Connected Stock and Old Manager's Connected Stock are mutually exclusive sets, while New Manager's Stock and Old Manager's Stock can both be equal to 1 since the new manager and old manager can both hold the same stock.

The results in Table $\mathrm{X}$ indicate that on average, new managers tend to unwind previous managers' positions and replace them with fresh ones (coefficients on New Manager's Stock and Old Manager's Stock), but controlling for this effect, managers show a tendency to immediately place significant larger bets in stocks within their network. ${ }^{21}$ Looking at column 1, the coefficient on New Manager's

${ }^{21}$ Jin and Scherbina (2006) find evidence that new managers sell inherited momentum losers. Running these regressions interacting all categorical variables with past returns, and with categorical variables for negative past returns, did not change the magnitude or significance of the 
Connected Stock implies that the new manager nearly doubles the weight in stocks within his network (from 55 to 101 basis points), a large and statistically significant effect. Looking at sales of stocks previously owned by the old manager, although the decrease in weights is larger for previously-connected stocks, we are unable to reject the null hypothesis of no difference in behavior between connected and non-connected securities. Taken together, these results suggest that new managers unwind previous managers' positions unconditionally, and immediately place larger bets in stocks within her networks relative to all newly chosen positions.

\section{Fund manager behavior}

In this section we further examine the trading behavior of the fund managers in our sample. As demonstrated in Section IV, fund managers tend to place larger concentrated bets on companies to which they are connected through their education network. Specifically, among the stocks they choose to hold, managers place a greater weight on connected stocks relative to non-connected stocks. A separate but related question is the extent to which fund managers unconditionally overweight all connected stocks. Panel A reports the average fraction of fund holdings invested in connected securities, the average fraction of connected securities in the market portfolio, and the difference between them. Panel A shows that fund managers tend to underweight connected stocks relative to their weights in the market portfolio, for all four connection definitions. This result suggests that managers do not simply overweight all connected stocks, as a familiarity explanation might suggest, but instead actively decide which connected stocks to hold and which not to hold. And for those connected stocks that they do choose to hold, they place large bets on them and earn large abnormal returns on them, consistent with comparative advantages in the collection of information through a network.

Given the large abnormal returns to investing in connected stocks that we

results.

The Small World of Investing - Page 24 
document in this paper, a natural follow-up question is: why don't fund managers invest even more of their portfolio in connected stocks? To explore this question we conduct two tests. The first test is to compute the average Sharpe ratios of individual mutual funds' connected holdings and overall holdings (unlike the Sharpe ratios shown in Table 4, which are computed at the aggregate mutual fund portfolio level). As shown in Panel B, the average Sharpe ratio at the individual fund level on CONNECTED1 stocks is significantly lower than the average Sharpe ratio at the fund level for all holdings (.37 compared to .52); we obtain similar results for the other three connection definitions. This result suggests that for a given mutual fund, it may not be optimal to invest more in connected stocks given the fact that this would yield a more undiversified portfolio.

To address this question formally, we conduct a second test to identify the managers for whom it would have been optimal to invest more in connected stocks during our sample period. Specifically, for each fund manager, we run a time-series regression of the fund's monthly return in connected securities on the fund's total return. A significant alpha in this regression indicates that a fund manager could have chosen some linear combination of the left- and right-hand side portfolios in order to have increased his in-sample Sharpe ratio. We compute the percentage of funds for which we are able to reject the null hypothesis that the alpha is equal to zero, i.e., the percentage of funds that chose a sub-optimal weight in connected stocks in-sample. Column 3 of Panel B shows that this number ranges from $1.9 \%$ of funds (for CONNECTED4 stocks) to $5.4 \%$ of funds (for CONNECTED1 stocks), indicating that very few funds would have been made better off by investing more than what they already did in connected stocks during our sample period.

We also investigate the extent to which fund managers who are connected to each other through shared educational backgrounds tend to herd in their trading decisions, particularly on connected stocks. We explore this issue by identifying, for a given portfolio manager $j$, all fund managers that attended the same academic institution as manager $j$; we then sum up the dollar holdings of this connected manager portfolio (excluding manager $j$ s holdings). To test connected manager herding, we regress the change in the percentage holding of a stock $\left(d_{w}\right)$ by a given 
fund manager $j$ in a given quarter on the change in the connected manager portfolio $\left(D W_{M C}\right)$ for that stock in that quarter. We also interact this connected manager portfolio with a dummy variable $(Z 1)$ equal to one if the stock in question is a connected stock, to test if fund managers herd with managers to whom they are connected and specifically on connected stocks. Panel C in Table XI shows that fund managers' trades are significantly positively related to the trades of managers to whom they are connected (i.e., connected managers herd with each other), even controlling for the overall tendency of managers to herd with each other (captured by $D W_{A L L}$, the change in the overall mutual fund portfolio for a given stock). Further, the positive and significant coefficient on the interaction term $\left(D W_{M C}{ }^{*} Z 1\right)$ indicates that connected managers herd more with each other especially on connected stocks.

\section{Conclusions}

This paper suggests that social networks are important for information flow between firms and investors. Specifically, we provide evidence consistent with the hypothesis that the social network formed through education links allows portfolio managers to gather information on firms. We find that portfolio managers place larger concentrated bets on stocks they are connected to through their education network, and do significantly better on these holdings relative to non-connected holdings, and relative to connected firms they choose not to hold. A portfolio of connected stocks held by managers outperforms non-connected stocks by up to $8.4 \%$ per year. This connection premium is not driven by firm, fund, school, industry, or geographic location effects, and is not driven by a subset of the school connections (ex. Ivy League). Further, we find that the bulk of this premium occurs around corporate news events such as earnings announcements, lending support to the hypothesis that the excess return earned on connected stocks is driven by information flowing through the network.

We believe social networks provide a natural framework to test the flow of private information into security prices. Information can be followed in a predictable path along the network. Further, as the information will eventually be revealed into stock prices, advance knowledge implies return predictability. In this 
paper we exploit education networks between portfolio managers and firm senior officers. The advantage of these educations networks is that they are formed on average decades before the private information being transferred, and are most often independent of the information being transferred. What we document using these networks is not an isolated situation or constrained to a few portfolio managers or firms, but rather a systematic effect across the entire universe of U.S. firms and portfolio managers. We believe the avenue of future research in social networks should examine both various forms of social networks and to what extent different types of information are delivered across different networks. Understanding these issues could give a better idea of how information flows, and how investors receive information, in security markets and so allow us to better predict how and when prices will respond to new information. 


\section{References}

Baker, Malcolm, Lubomir Litov, Jessica A. Wachter, and Jeffrey Wurgler, 2005, Can mutual fund managers pick stocks? Evidence from their trades prior to earnings announcements, Working paper, NYU.

Berk, Jonathan B., and Richard C. Green, 2004, Mutual fund flows and performance in rational markets, Journal of Political Economy 112, 1269-1295.

Brown, Stephen J., and William N. Goetzmann, 1995, Performance persistence, Journal of Finance 50, 679-698.

Carhart, Mark, 1997, On persistence in mutual fund performance, Journal of Finance 52, 57-82.

Chen, Joseph, Harrison Hong, Ming Huang, and Jeffrey D. Kubik, 2004, Does fund size erode mutual fund performance? The role of liquidity and organization, American Economic Review 94, 1276-1302.

Chevalier, Judith, and Glenn Ellison, 1999, Are some mutual fund managers better than others? Cross-sectional patterns in behavior and performance, Journal of Finance 54, 875-899.

Christoffersen, Susan, and Sergei Sarkissian, 2002, Location overconfidence, Working paper, McGill University.

Cohen, Randolph, Joshua Coval, and Lubos Pastor, 2005, Judging managers by the company they keep, Journal of Finance 60, 1057-1098.

Conyon, Martin J., and Mark R. Muldoon, 2006, The small world of corporate boards, Journal of Business Finance and Accounting 33, 1321-1343.

Coval, Joshua, and Tobias Moskowitz, 1999, Home bias at home: Local equity preference in domestic portfolios, Journal of Finance 54, 2045-2074.

Coval, Joshua, and Tobias Moskowitz, 2001, The geography of investment: Informed trading and asset prices, Journal of Political Economy 109, 811841.

Daniel, Kent, Mark Grinblatt, Sheridan Titman, and Russ Wermers, 1997, Measuring mutual fund performance with characteristic-based benchmarks, Journal of Finance 52, 394-415.

Davis, Gerald F., 1991, Agents without principles? The spread of the poison pill through the inter-corporate network, Administrative Science Quarterly 36, 583-613.

Elton, Edwin J., Martin J. Gruber, Sanjiv Das, and Matt Hlavka, 1993, Efficiency with costly information: A re-interpretation of evidence from managed 
portfolios, Review of Financial Studies 6, 1-21.

Faccio, Mara, 2006, Politically connected firms, American Economic Review 96, 369-386.

Feld, Scott, 1982, Social structural determinants of similarity among associates, American Sociological Review 47, 797-801.

Fischer, Claude, Robert Jackson Ann Stueve, Kathleen Gerson, Lynne Jones. 1977. Networks and Places. New York: Free Press.

Fisman, David, Ray Fisman, Julia Galef, and Rakesh Khurana, 2006, Estimating the value of connections to Vice-President Cheney, Working paper, Columbia University.

Flap, Henk and Matthijs Kalmijn. 2001 "Assortative meeting and mating: Unintended consequences of organized settings for partner choices." Social Forces 79(4) 1289-1312.

Giving Institute, The. 2006 Giving USA 2006. Giving USA Foundation.

Goetzmann, William N., and Roger G. Ibbotson, 1994, Do winners repeat? Patterns in mutual fund performance, Journal of Portfolio Management 20, 9-18.

Grinblatt, Mark, and Sheridan Titman, 1989, Mutual fund performance: An analysis of quarterly portfolio holdings, Journal of Business 62, 394-415.

Grinblatt, Mark, and Sheridan Titman, 1993, Performance measurement without benchmarks: An examination of mutual fund returns, Journal of Business 66, 47-68.

Grinblatt, Mark, Sheridan Titman, and Russ Wermers, 1995, Momentum investment strategies,, portfolio performance, and herding: A study of mutual fund behavior, American Economic Review 85, 1088-1105.

Grossman, Sanford and Joseph Stiglitz. 1976 "Information and competitive price systems." American Economic Review 66-2 246-253.

Gruber, Martin J., 1996, Another puzzle: The growth in actively managed mutual funds, Journal of Finance 51, 783-810.

Hallock, K. F., 1997, Reciprocally interlocking board of directors and executive compensation, Journal of Financial and Quantitative Analysis 32, 331-344.

Haunschild, Pamela R., 1993, Interorganizational imitation: The impact of interlocks on corporate acquisition activity, Administrative Science Quarterly $38,564-592$. 
Hendricks, Darryll, Jayendu Patel, and Richard Zeckhauser, 1993, Hot hands in mutual funds: Short-run persistence of performance, 1974-1988, Journal of Finance 48, 93-130.

Hochberg, Yael, Alexander Ljungqvist, and Yang Lu, 2005, Whom you know matters: Venture capital networks and investment performance, Journal of Finance forthcoming.

Hong, Harrison, Jeffrey D. Kubik, and Jeremy C. Stein, 2004, Social interaction and stock market participation, Journal of Finance 59, 137-163.

Hong, Harrison, Jeffrey D. Kubik, and Jeremy C. Stein, 2005, Thy neighbor's portfolio: Word-of-mouth effects in the holdings and trades of money managers, Journal of Finance 60, 2801-2824.

Huberman, Gur, 2001, Familiarity breeds investment, Review of Financial Studies 14, 659-680.

Jackson, Matthew O., 2005, The economics of social networks, in Richard Blundell, Whitney Newey, and Torsten Persson, (eds.) Proceedings of the $9^{\text {th }}$ World Congress of the Econometric Society, Oxford University Press forthcoming.

Jegadeesh, Narasimhan, and Sheridan Titman, 1993, Returns to buying winners and selling losers: Implications for stock market efficiency, Journal of Finance $48,65-91$.

Jensen, Michael C., 1968, The performance of mutual funds in the period 19451964, Journal of Finance 23, 389-416.

Jin, Li, and Anna Scherbina, 2006, Inheriting Losers, Working paper, HBS.

Khurana, Rakesh, 2002, Searching for a corporate savior: The irrational quest for charismatic CEOS, Princeton University Press.

Kuhnen, Camelia M., 2005, Social networks, corporate governance and contracting in the mutual fund industry, Working paper, Stanford University.

Larcker, David F., Scott A. Richardson, Andrew J. Seary, and Irem Tuna, 2005, Back door links between directors and executive compensation, Working paper, University of Pennsylvania.

Lazarsfeld, Paul and Robert Merton. 1954 "Friendship as social process: a substantive and methodological analysis." Freedom and Control in Modern Society. (eds) Morroe Berger, Theodore Abel, and Charles Page 18-66.

Malkiel, Burton G., 1995, Returns from investing in equity mutual funds 19711991, Journal of Finance 50, 549-572. 
Massa, Massimo, and Simonov, 2005, History versus geography, working paper, Stockholm School of Economics.

McPherson, M., L. Smith-Lovin and J. Cook. (2001). Birds of a feather: Homophily in Social Networks. Annual Review of Sociology. 27:415-44.

Mizruchi, Mark S., 1982, The American Corporate Network, 1904-1974, Beverly Hills: Sage Publications.

Mizruchi, Mark S., 1992, The Structure of Corporate Political Action: Inter-firm Relations and Their Consequences, Harvard University Press.

Parkin, Rachel, 2006, Legal careers and school connections, Harvard University working paper.

Perez-Gonzales, Francisco, 2006, Inherited control and firm performance, American Economic Review 96, 1559-1588.

Richardson, Helen. 1940 "Community of values as a factor in friendships of college and adult women." Journal of Social Psychology 11 303-312.

Useem, Michael, 1984, The Inner Circle, Oxford: Oxford University Press.

Wermers, Russ, 1997, Momentum investment strategies of mutual funds, performance persistence, and survivorship bias, Working paper, University of Colorado. 


\section{Table I: Summary statistics: mutual funds}

This table shows summary statistics as of December of each year for the sample of mutual funds and their common stock holdings between 1990 and 2006. We include in the sample of funds/portfolio managers actively-managed, domestic equity mutual funds from the merged CDA/Spectrum - Morningstar data with a self-declared investment objective of aggressive growth, growth, or growth-and-income and non missing information on the portfolio manager's identity and educational background. The sample of stocks includes the funds' holdings in common stocks (CRSP share codes 10 or 11) from the merged CRSP/BOARDEX data with non missing information on the educational background of members of the board of directors and senior officers of the firm (CEO, CFO or Chairman). "Fund turnover in portfolio managers" is the fraction of funds with at least one complete manager(s) replacement during the calendar year.

\begin{tabular}{|c|c|c|c|c|c|}
\hline Panel A: Time series (annual observations, 1990-2006) & mean & median & $\min$ & $\max$ & Stdev \\
\hline Number of funds per year & 709 & 747 & 331 & 924 & 168 \\
\hline Number of portfolio managers per year & 821 & 825 & 397 & 1,174 & 197 \\
\hline$\%$ of active equity fund universe (\% of funds) & 0.75 & 0.74 & 0.67 & 0.86 & 0.06 \\
\hline$\%$ of active equity fund universe ( $\%$ of total assets) & 0.84 & 0.85 & 0.74 & 0.94 & 0.05 \\
\hline Fund turnover in portfolio managers (\% of funds) & 0.14 & 0.14 & 0.06 & 0.32 & 0.06 \\
\hline Fund turnover in portfolio managers ( $\%$ of total assets) & 0.14 & 0.13 & 0.05 & 0.33 & 0.08 \\
\hline Number of firms per year & 4,543 & 4,462 & 3,281 & 5,881 & 864 \\
\hline Number of board members per year & 25,027 & 25,540 & 12,569 & 35,754 & 8,285 \\
\hline Number of firm's senior officers per year & 7,207 & 7,798 & 3,446 & 9,698 & 2,296 \\
\hline$\%$ of CRSP common stock universe (\% of stocks) & 0.76 & 0.78 & 0.59 & 0.89 & 0.10 \\
\hline$\%$ of CRSP common stock universe (\% of total market value) & 0.96 & 0.97 & 0.91 & 0.99 & 0.03 \\
\hline Number of academic institutions per year & 354 & 359 & 218 & 406 & 49 \\
\hline Panel B: Pooled firm-year or fund-year observation & mean & median & $\min$ & $\max$ & Stdev \\
\hline Number of academic institutions per firm & 9.8 & 7.0 & 1.0 & 139.0 & 9.4 \\
\hline Number of board members per academic institution & 64.9 & 20.0 & 1.0 & 3954.0 & 173.1 \\
\hline Number of firm's senior officers per academic institution & 21.7 & 7.0 & 1.0 & 1159.0 & 54.9 \\
\hline Number of academic institutions per fund & 2.9 & 2.0 & 1.0 & 25.0 & 2.5 \\
\hline Number of portfolio managers per academic institution & 6.0 & 2.0 & 1.0 & 130.0 & 11.2 \\
\hline Number of board members per firm & 4.1 & 3.0 & 1.0 & 26.0 & 3.1 \\
\hline
\end{tabular}




\section{Table II: Summary statistics: academic institutions}

This table shows summary statistics of the sample of academic institutions between 1990 and 2006. We include in the sample of funds/managers all actively-managed, domestic equity mutual funds from the merged $\mathrm{CDA}$ /Spectrum-Morningstar database with a self-declared investment objective of aggressive growth, growth, or growth-and-income and non missing information on the portfolio manager's identity and the manager's educational background. The sample of stocks includes the funds' holdings in common stocks (CRSP share codes 10 or 11) from the merged CRSP/BOARDEX data with non missing information on the educational background of members of the board of directors and senior officers of the firm (defined as CEO, CFO or Chairman). Panel A shows the top 5 most connected academic institutions, ranked by the average number of connected firms (portfolio managers) over the period 1990 to 2006. In this table an institution is defined as connected to a firm (fund) if a senior officer (portfolio manager) holds any degree from that that institution. Panel B shows the distribution of degrees and graduation years over the entire sample.

\begin{tabular}{|c|c|c|c|c|c|c|}
\hline \multicolumn{4}{|c|}{ Firm's senior officers } & \multicolumn{3}{|c|}{ Portfolio managers } \\
\hline & Academic institution & $\begin{array}{c}\text { Average \# } \\
\text { of firms }\end{array}$ & $\begin{array}{l}\text { Average \% of } \\
\text { CRSP firms }\end{array}$ & Academic institution & $\begin{array}{c}\text { Average \# } \\
\text { of managers }\end{array}$ & $\begin{array}{l}\text { Average } \% \\
\text { of managers }\end{array}$ \\
\hline 1 & Harvard University & 1,014 & 0.12 & Harvard University & 147 & 0.16 \\
\hline 2 & Stanford University & 384 & 0.05 & University of Pennsylvania & 98 & 0.11 \\
\hline 3 & University of Pennsylvania & 325 & 0.04 & Columbia University & 90 & 0.09 \\
\hline 4 & Columbia University & 257 & 0.03 & University of Chicago & 92 & 0.09 \\
\hline 5 & University of Chicago & 201 & 0.02 & New York University & 85 & 0.08 \\
\hline \multicolumn{7}{|c|}{ Panel B: distribution of degree and graduation years } \\
\hline \multicolumn{2}{|c|}{ Degree } & $\begin{array}{l}\text { Firm's senior } \\
\text { officers }\end{array}$ & $\begin{array}{l}\text { Portfolio } \\
\text { managers }\end{array}$ & Graduation year & $\begin{array}{l}\text { Firm's senior } \\
\text { officers }\end{array}$ & $\begin{array}{l}\text { Portfolio } \\
\text { managers }\end{array}$ \\
\hline \multicolumn{2}{|c|}{ Business school } & 0.37 & 0.58 & $\leq 1950$ & 0.01 & 0.02 \\
\hline \multicolumn{2}{|r|}{ Medical school } & 0.01 & 0.00 & $1950-1959$ & 0.12 & 0.05 \\
\hline \multicolumn{2}{|r|}{ Graduate (nondescript) } & 0.18 & 0.14 & $1960-1969$ & 0.34 & 0.25 \\
\hline \multicolumn{2}{|c|}{ PH.D. } & 0.06 & 0.03 & $1970-1979$ & 0.33 & 0.31 \\
\hline \multicolumn{2}{|c|}{ Law School } & 0.07 & 0.02 & $1980-1989$ & 0.17 & 0.32 \\
\hline \multicolumn{2}{|c|}{ Undergraduate } & 0.86 & 0.91 & $\geq 1990$ & 0.02 & 0.06 \\
\hline
\end{tabular}




\section{Table III: OLS regression, portfolio weights in connected vs. non-connected stocks}

This table reports pooled OLS quarterly regressions of mutual funds' portfolio weights in connected and non-connected stocks. The sample period is 1990-2006 and the units of observation are fund-stock-quarter. The dependent variable in the regressions is the fund's dollar investment in a stock as a percentage of total net assets of the fund $(w)$. The independent variables of interest are those measuring the connection of the portfolio manager to the given firm. In Panel A, these are categorical variables for whether a senior officer (CEO, CFO, or Chairman) of the given firm and the given mutual fund manager attended the (i) same school CONNECTED1, (ii) the same school and received the same degree CONNECTED2, (iii) the same school and overlapped in years CONNECTED3, and (iv) the same school, received the same degree, and overlapped in years CONNECTED4. The control variables included where indicated are: \%STYLE, the percentage of the fund's total net assets invested in the style corresponding to the stock being considered (style is calculated as in DGTW (1997)), ME, BM and R12 which are percentiles of market value of equity, book to market, and past 12 month return. Panel B differs from Panel A in that the connections are orthogonalized to one another. So, CONNECTED1 measures the case where the portfolio manager and senior officer attended the same school, but did not receive the same degree nor overlap in years. CONNECTED2 in Panel B measures cases of the same school and same degree, but no overlap in years, while CONNECTED3 measures cases of the same school and year overlap, but not the same degrees. Quarter fixed effects are included in each regression, and industry (Fama-French 48), firm, fund's investment objective code (IOC), and fund fixed effects are included where indicated. Standard errors are adjusted for clustering at the quarter level and are reported in brackets below the coefficient estimates. $5 \%$ statistical significance is indicated in bold.

\begin{tabular}{|c|c|c|c|c|c|c|c|c|c|c|}
\hline $\begin{array}{l}\text { Panel A: OLS regression } \\
\text { Basic connection measure }\end{array}$ & 1 & 2 & 3 & 4 & 5 & 6 & 7 & 8 & 9 & 10 \\
\hline Constant & $\begin{array}{l}89.4 \\
{[0.05]}\end{array}$ & $\begin{array}{c}90.0 \\
{[0.03]}\end{array}$ & $\begin{array}{c}90.4 \\
{[0.01]}\end{array}$ & $\begin{array}{c}90.5 \\
{[0.00]}\end{array}$ & $\begin{array}{l}89.4 \\
{[0.05]}\end{array}$ & $\begin{array}{l}-57.2 \\
{[2.85]}\end{array}$ & $\begin{array}{l}-57.9 \\
{[2.40]}\end{array}$ & $\begin{array}{l}-32.9 \\
{[4.34]}\end{array}$ & $\begin{array}{l}-66.4 \\
{[2.46]}\end{array}$ & $\begin{array}{l}-27.4 \\
{[2.91]}\end{array}$ \\
\hline $\begin{array}{l}\text { CONNECTED1 } \\
\text { Same School }\end{array}$ & $\begin{array}{l}28.45 \\
{[1.30]}\end{array}$ & & & & $\begin{array}{l}28.02 \\
{[1.23]}\end{array}$ & $\begin{array}{l}10.01 \\
{[0.58]}\end{array}$ & $\begin{array}{l}9.76 \\
{[0.55]}\end{array}$ & $\begin{array}{c}2.79 \\
{[0.66]}\end{array}$ & $\begin{array}{l}10.37 \\
{[0.58]}\end{array}$ & $\begin{array}{c}9.02 \\
{[0.39]}\end{array}$ \\
\hline $\begin{array}{l}\text { CONNECTED2 } \\
\text { Same School, same degree }\end{array}$ & & $\begin{array}{l}27.03 \\
{[1.59]}\end{array}$ & & & & & & & & \\
\hline $\begin{array}{l}\text { CONNECTED3 } \\
\text { Same School, year overlap }\end{array}$ & & & $\begin{array}{l}41.42 \\
{[3.43]}\end{array}$ & & & & & & & \\
\hline $\begin{array}{l}\text { CONNECTED } 4 \\
\text { Same School, same degree, year overlap }\end{array}$ & & & & $\begin{array}{l}40.00 \\
{[4.55]}\end{array}$ & $\begin{array}{l}13.14 \\
{[3.82]}\end{array}$ & $\begin{array}{l}10.16 \\
{[3.35]}\end{array}$ & $\begin{array}{l}10.61 \\
{[3.37]}\end{array}$ & $\begin{array}{l}8.37 \\
{[3.23]}\end{array}$ & $\begin{array}{l}10.51 \\
{[3.29]}\end{array}$ & $\begin{array}{l}11.97 \\
{[2.32]}\end{array}$ \\
\hline Controls & No & No & No & No & No & Yes & Yes & Yes & Yes & Yes \\
\hline Fixed effect & Quarter & Quarter & Quarter & Quarter & Quarter & Quarter & Quarter & Quarter & Quarter & Quarter \\
\hline Fixed effect & & & & & & & Industry & Firm & $\mathrm{IOC}$ & Fund \\
\hline $\mathrm{R} 2$ & 0.01 & 0.01 & 0.01 & 0.01 & 0.01 & 0.17 & 0.18 & 0.22 & 0.17 & 0.49 \\
\hline
\end{tabular}


Table III (continued): OLS regression, portfolio weights in connected vs. non-connected stocks

\begin{tabular}{|c|c|c|c|c|c|c|c|c|c|}
\hline $\begin{array}{l}\text { Panel B: OLS regression } \\
\text { orthogonal connection measure }\end{array}$ & 1 & 2 & 3 & 4 & 5 & 6 & 7 & 8 & 9 \\
\hline Constant & $\begin{array}{l}90.0 \\
{[0.02]}\end{array}$ & $\begin{array}{c}90.0 \\
{[0.02]}\end{array}$ & $\begin{array}{c}90.5 \\
{[0.00]}\end{array}$ & $\begin{array}{l}89.4 \\
{[0.04]}\end{array}$ & $\begin{array}{l}-57.2 \\
{[2.85]}\end{array}$ & $\begin{array}{l}-57.9 \\
{[2.40]}\end{array}$ & $\begin{array}{l}-32.8 \\
{[4.34]}\end{array}$ & $\begin{array}{l}-66.4 \\
{[2.46]}\end{array}$ & $\begin{array}{l}-27.5 \\
{[2.91]}\end{array}$ \\
\hline $\begin{array}{l}\text { CONNECTED1 } \\
\text { Same School only }\end{array}$ & $\begin{array}{l}27.6 \\
{[1.32]}\end{array}$ & & & $\begin{array}{c}28.2 \\
{[1.32]}\end{array}$ & $\begin{array}{l}11.74 \\
{[0.65]}\end{array}$ & $\begin{array}{l}11.09 \\
{[0.65]}\end{array}$ & $\begin{array}{c}3.58 \\
{[0.80]}\end{array}$ & $\begin{array}{l}12.23 \\
{[0.65]}\end{array}$ & $\begin{array}{l}7.92 \\
{[0.55]}\end{array}$ \\
\hline $\begin{array}{l}\text { CONNECTED2 } \\
\text { Same School, same degree, no overlap }\end{array}$ & & $\begin{array}{c}26.0 \\
{[1.45]}\end{array}$ & & $\begin{array}{c}26.1 \\
{[1.43]}\end{array}$ & $\begin{array}{l}7.20 \\
{[0.90]}\end{array}$ & $\begin{array}{c}7.26 \\
{[0.86]}\end{array}$ & $\begin{array}{l}1.01 \\
{[0.79]}\end{array}$ & $\begin{array}{c}7.37 \\
{[0.91]}\end{array}$ & $\begin{array}{l}9.55 \\
{[0.60]}\end{array}$ \\
\hline $\begin{array}{l}\text { CONNECTED3 } \\
\text { Same School, year overlap, not same degree }\end{array}$ & & & $\begin{array}{c}42.6 \\
{[3.13]}\end{array}$ & $\begin{array}{c}38.6 \\
{[3.03]}\end{array}$ & $\begin{array}{l}20.1 \\
{[2.66]}\end{array}$ & $\begin{array}{l}20.9 \\
{[2.62]}\end{array}$ & $\begin{array}{l}12.8 \\
{[2.38]}\end{array}$ & $\begin{array}{l}20.96 \\
{[2.58]}\end{array}$ & $\begin{array}{c}9.04 \\
{[1.92]}\end{array}$ \\
\hline Controls & No & No & No & No & Yes & Yes & Yes & Yes & Yes \\
\hline Fixed effect & Quarter & Quarter & Quarter & Quarter & Quarter & Quarter & Quarter & Quarter & Quarter \\
\hline Fixed effect & & & & & & Industry & Firm & $\mathrm{IOC}$ & Fund \\
\hline $\mathrm{R} 2$ & 0.01 & 0.01 & 0.01 & 0.01 & 0.17 & 0.18 & 0.22 & 0.17 & 0.49 \\
\hline
\end{tabular}


Table IV: Returns on connected holdings, 1990 - 2006

This table shows calendar time portfolio excess returns. At the beginning of every calendar quarter stocks in each mutual fund portfolio (based on the most recent SEC filing) are assigned to one of two portfolios (connected and non-connected). In this table, connected companies are defined as firms where at least a senior official (CEO, CFO or Chairman) received the same degree from the same institution as the fund's portfolio manager, and overlapped with the portfolio manager during the pursuit of the degree. We compute monthly returns on connected and non-connected holdings between reports based on the assumption that funds did not change their holding between reports. Portfolios are rebalanced every calendar quarter and within a given fund portfolio, stocks are weighted by the fund's dollar holdings. Finally, we compute value weighted calendar time portfolios by averaging across funds, weighting individual fund portfolios by the fund's total net asset value at the end of the previous quarter. This table includes all available stocks and all available funds. We report average portfolio returns minus Treasury bill returns in the period 1990 to 2006. Returns are in annual percent, t-statistics are shown below the coefficient estimates. L/S is the annual average return of a zero cost portfolio that holds the portfolio of connected stocks and sells short the portfolio of non-connected stocks. t-statistics are shown below the coefficient estimates, and $5 \%$ statistical significance is indicated in bold.

\begin{tabular}{lcccc}
\hline $\begin{array}{l}\text { Annual value-weighted } \\
\text { excess returns }\end{array}$ & All holdings & $\begin{array}{c}\text { Connected } \\
\text { holdings }\end{array}$ & Non-connected & L/S \\
Mean & 7.81 & 16.05 & 7.69 & 8.36 \\
t-statistic & $(1.73)$ & $(3.28)$ & $(1.71)$ & $(3.78)$ \\
Std deviation & 18.59 & 20.17 & 18.54 & 9.12 \\
Skewness & -0.96 & -1.54 & -0.96 & -0.42 \\
Kurtosis & -0.30 & 0.31 & -0.32 & -0.19 \\
Sharpe ratio & 0.42 & 0.80 & 0.41 & 0.92 \\
\hline
\end{tabular}




\section{Table V: Connected holdings, abnormal returns $1990-2006$}

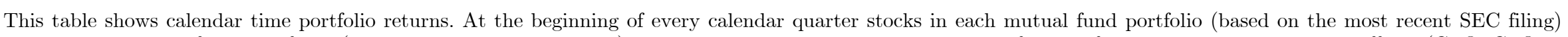

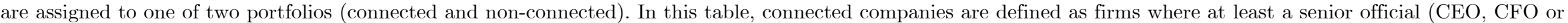

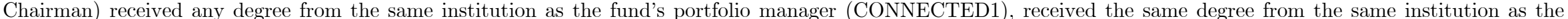

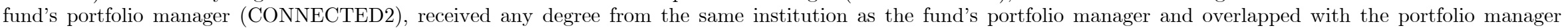

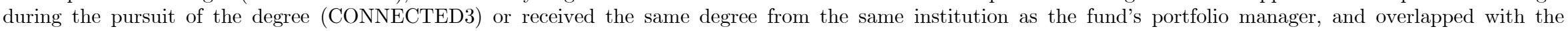

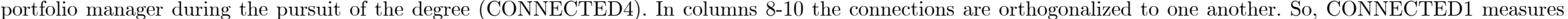

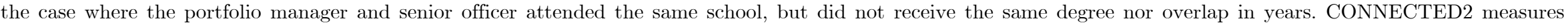

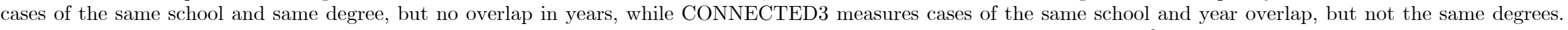

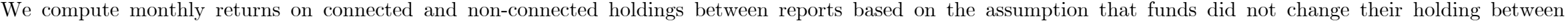

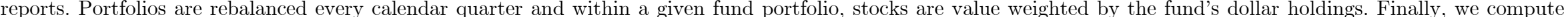

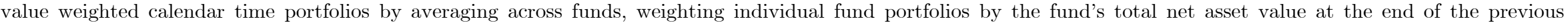

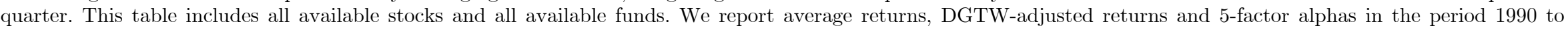

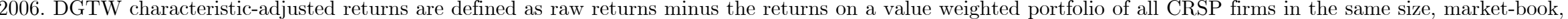
and one year momentum quintile. Alpha is the intercept on a regression of monthly portfolio excess returns. The explanatory variables are the monthly returns from

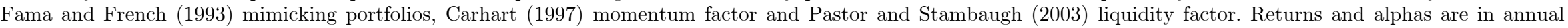

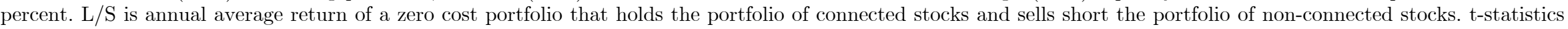
are shown below the coefficient estimates, and $5 \%$ statistical significance is indicated in bold.

\begin{tabular}{|c|c|c|c|c|c|c|c|c|c|}
\hline \multirow{3}{*}{$\begin{array}{l}\text { Value weighted annual returns } \\
\text { All holdings }\end{array}$} & \multicolumn{2}{|c|}{ Raw return } & \multicolumn{2}{|c|}{ DGTW-adjusted return } & \multicolumn{2}{|c|}{ 5-factor alpha } & \multicolumn{3}{|c|}{ Orthogonal connection measure } \\
\hline & & & & & & & Raw & DGTW & 5 -factor \\
\hline & $\begin{array}{l}11.85 \\
(2.62)\end{array}$ & & $\begin{array}{c}0.41 \\
(0.89)\end{array}$ & & $\begin{array}{c}0.08 \\
(0.14)\end{array}$ & & return & & \\
\hline \multirow[t]{2}{*}{ Not connected } & $\begin{array}{l}11.73 \\
(2.60)\end{array}$ & & $\begin{array}{c}0.37 \\
(0.85)\end{array}$ & & $\begin{array}{l}-0.04 \\
(-0.06)\end{array}$ & & & & \\
\hline & $\begin{array}{c}\text { Connected } \\
\text { holdings }\end{array}$ & $\mathrm{L} / \mathrm{S}$ & $\begin{array}{l}\text { Connected } \\
\text { holdings }\end{array}$ & $\mathrm{L} / \mathrm{S}$ & $\begin{array}{l}\text { Connected } \\
\text { holdings }\end{array}$ & $\mathrm{L} / \mathrm{S}$ & $\mathrm{L} / \mathrm{S}$ & $\mathrm{L} / \mathrm{S}$ & $\mathrm{L} / \mathrm{S}$ \\
\hline $\begin{array}{l}\text { CONNECTED1 } \\
\text { Same School }\end{array}$ & $\begin{array}{l}14.76 \\
(3.00)\end{array}$ & $\begin{array}{c}3.03 \\
(2.74)\end{array}$ & $\begin{array}{c}2.06 \\
(2.63)\end{array}$ & $\begin{array}{l}1.69 \\
(2.62)\end{array}$ & $\begin{array}{c}2.92 \\
(3.16)\end{array}$ & $\begin{array}{c}2.96 \\
(3.40)\end{array}$ & $\begin{array}{c}2.50 \\
(2.29)\end{array}$ & $\begin{array}{l}1.55 \\
(2.17)\end{array}$ & $\begin{array}{c}2.35 \\
(2.33)\end{array}$ \\
\hline $\begin{array}{l}\text { CONNECTED2 } \\
\text { Same School, same degree }\end{array}$ & $\begin{array}{l}15.44 \\
(3.13)\end{array}$ & $\begin{array}{c}3.71 \\
(3.25)\end{array}$ & $\begin{array}{l}2.29 \\
(2.52)\end{array}$ & $\begin{array}{l}1.91 \\
(2.58)\end{array}$ & $\begin{array}{c}3.25 \\
(3.17)\end{array}$ & $\begin{array}{c}3.28 \\
(3.21)\end{array}$ & $\begin{array}{c}3.46 \\
(3.06)\end{array}$ & $\begin{array}{l}1.81 \\
(2.39)\end{array}$ & $\begin{array}{c}3.04 \\
(2.99)\end{array}$ \\
\hline $\begin{array}{l}\text { CONNECTED3 } \\
\text { Same School, year overlap }\end{array}$ & $\begin{array}{l}18.58 \\
(3.66)\end{array}$ & $\begin{array}{c}6.85 \\
(4.62)\end{array}$ & $\begin{array}{l}4.78 \\
(3.63)\end{array}$ & $\begin{array}{c}4.41 \\
(4.25)\end{array}$ & $\begin{array}{c}6.50 \\
(3.76)\end{array}$ & $\begin{array}{c}6.54 \\
(3.80)\end{array}$ & $\begin{array}{c}5.03 \\
(1.52)\end{array}$ & $\begin{array}{c}4.06 \\
(0.52)\end{array}$ & $\begin{array}{c}5.05 \\
(1.82)\end{array}$ \\
\hline $\begin{array}{l}\text { CONNECTED } 4 \\
\text { Same School, same degree, year overlap }\end{array}$ & $\begin{array}{l}20.08 \\
(4.02)\end{array}$ & $\begin{array}{c}8.36 \\
(3.78)\end{array}$ & $\begin{array}{c}5.83 \\
(3.24)\end{array}$ & $\begin{array}{c}5.46 \\
(3.30)\end{array}$ & $\begin{array}{c}8.70 \\
(3.80)\end{array}$ & $\begin{array}{c}8.74 \\
(3.80)\end{array}$ & & & \\
\hline
\end{tabular}


Table VI: Connected holdings not held, abnormal returns $1990-2006$

This table shows calendar time portfolio returns. At the beginning of every calendar quarter stocks in each mutual fund portfolio (based on the most recent SEC filing) are assigned to one of two portfolios (connected and non-connected). In this table, connected companies are defined as firms where at least a senior official (CEO, CFO or Chairman) received any degree from the same institution as the fund's portfolio manager (CONNECTED1), received the same degree from the same institution as the fund's portfolio manager (CONNECTED2), received any degree from the same institution as the fund's portfolio manager and overlapped with the portfolio manager during the pursuit of the degree (CONNECTED3) or received the same degree from the same institution as the fund's portfolio manager, and overlapped with the portfolio manager during the pursuit of the degree (CONNECTED4). We compute monthly returns on connected and nonconnected holdings between reports based on the assumption that funds did not change their holding between reports. Portfolios are rebalanced every calendar quarter and within a given fund portfolio, stocks are value weighted by the fund's dollar holdings. Finally, we compute value weighted calendar time portfolios by averaging across funds, weighting individual fund portfolios by the fund's total net asset value at the end of the previous quarter. Similarly, we compute value weighted portfolios of connected stocks not held by the mutual fund managers. This table includes all available stocks and all available funds. Column 2 reports the average number of connected CRSP stocks ("all CRSP connected"), columns 3 and 4 report the equally weighted (EW) or value weighted (VW) fraction of connected stocks held by the aggregate mutual fund sector. In columns 5-10 we report average returns, and DGTW-adjusted returns. DGTW characteristicadjusted returns are defined as raw returns minus the returns on a value weighted portfolio of all CRSP firms in the same size, market-book, and one year momentum quintile. Returns and alphas are in annual percent. L/S is annual average return of a zero cost portfolio that holds the portfolio of connected stocks held by the funds and sells short the portfolio of connected stocks not held by the funds. t-statistics are shown below the coefficient estimates, and $5 \%$ statistical significance is indicated in bold.

\begin{tabular}{|c|c|c|c|c|c|c|c|c|c|}
\hline & \multicolumn{3}{|c|}{ Connected universe } & \multicolumn{3}{|c|}{ Return } & \multicolumn{3}{|c|}{ DGTW-adjusted return } \\
\hline & $\begin{array}{l}\text { All CRSP } \\
\text { connected }\end{array}$ & $\begin{array}{l}\% \text { held } \\
\text { EW }\end{array}$ & $\begin{array}{l}\% \text { held } \\
\text { VW }\end{array}$ & $\begin{array}{l}\text { Connected } \\
\text { not held }\end{array}$ & $\begin{array}{l}\text { Connected } \\
\text { held }\end{array}$ & $\mathrm{L} / \mathrm{S}$ & $\begin{array}{l}\text { Connected } \\
\text { not held }\end{array}$ & $\begin{array}{l}\text { Connected } \\
\text { held }\end{array}$ & $\mathrm{L} / \mathrm{S}$ \\
\hline $\begin{array}{l}\text { CONNECTED1 } \\
\text { Same School }\end{array}$ & 2,381 & 0.35 & 0.80 & $\begin{array}{l}13.06 \\
(2.94)\end{array}$ & $\begin{array}{l}14.76 \\
(3.00)\end{array}$ & $\begin{array}{c}1.70 \\
(1.46)\end{array}$ & $\begin{array}{c}0.71 \\
(1.67)\end{array}$ & $\begin{array}{l}2.06 \\
(2.63)\end{array}$ & $\begin{array}{l}1.35 \\
(2.15)\end{array}$ \\
\hline $\begin{array}{l}\text { CONNECTED2 } \\
\text { Same School, same degree }\end{array}$ & 2,258 & 0.23 & 0.65 & $\begin{array}{l}13.16 \\
(2.95)\end{array}$ & $\begin{array}{l}15.44 \\
(3.13)\end{array}$ & $\begin{array}{c}2.28 \\
(2.13)\end{array}$ & $\begin{array}{c}0.77 \\
(1.75)\end{array}$ & $\begin{array}{l}2.29 \\
(2.52)\end{array}$ & $\begin{array}{l}1.51 \\
(2.22)\end{array}$ \\
\hline $\begin{array}{l}\text { CONNECTED3 } \\
\text { Same School, year overlap }\end{array}$ & 1,592 & 0.09 & 0.42 & $\begin{array}{l}13.50 \\
(2.96)\end{array}$ & $\begin{array}{l}18.58 \\
(3.66)\end{array}$ & $\begin{array}{c}5.08 \\
(3.76)\end{array}$ & $\begin{array}{c}0.45 \\
(1.10)\end{array}$ & $\begin{array}{l}4.78 \\
(3.63)\end{array}$ & $\begin{array}{r}4.33 \\
(3.51)\end{array}$ \\
\hline $\begin{array}{l}\text { CONNECTED } 4 \\
\text { Same School, same degree, year overlap }\end{array}$ & 1,308 & 0.06 & 0.31 & $\begin{array}{l}13.76 \\
(2.96)\end{array}$ & $\begin{array}{l}20.08 \\
(4.02)\end{array}$ & $\begin{array}{c}6.32 \\
(3.50)\end{array}$ & $\begin{array}{c}0.78 \\
(0.34)\end{array}$ & $\begin{array}{c}5.83 \\
(3.24)\end{array}$ & $\begin{array}{l}5.05 \\
(2.89)\end{array}$ \\
\hline
\end{tabular}




\section{Table VII: Connected holdings, purchases and sells, abnormal returns $1990-2006$}

This table shows calendar time portfolio excess returns. At the beginning of every calendar quarter stocks purchased within each mutual fund portfolio (based on a comparison of the most recent SEC filing with the prior filing) are assigned to one of two portfolios (connected and non-connected). In this table, "purchases" are defined as first-time purchases of a stock ("pickups") plus all instances where a fund increases its portfolio weight in a given stock relative to its prior position; "sells" are defined as all instances where a fund decreases its portfolio weight in a given stock relative to its prior position, or sells off its entire remaining position in a stock. Connected companies are defined as firms where at least a senior official (CEO, CFO or Chairman) received any degree from the same institution as the fund's portfolio manager (CONNECTED1), received the same degree from the same institution as the fund's portfolio manager (CONNECTED2), received any degree from the same institution as the fund's portfolio manager and overlapped with the portfolio manager during the pursuit of the degree (CONNECTED3) or received the same degree from the same institution as the fund's portfolio manager, and overlapped with the portfolio manager during the pursuit of the degree (CONNECTED4). We compute monthly returns on connected and non-connected holdings between reports based on the assumption that funds did not change their holding between reports. Portfolios are rebalanced every calendar quarter and within a given fund portfolio, stocks are value weighted by the fund's dollar holdings. Finally, we compute value weighted calendar time portfolios by averaging across funds. Value weighted portfolios are computed by weighting individual fund value weighted portfolios by the fund's total net asset value at the end of the previous quarter. This table includes all available stocks and all available funds. We report average returns, DGTW-adjusted returns and 5-factor alphas in the period 1990 to 2006. DGTW characteristic-adjusted returns are defined as raw returns minus the returns on a value weighted portfolio of all CRSP firms in the same size, market-book, and one year momentum quintile. Alpha is the intercept on a regression of monthly portfolio excess returns. The explanatory variables are the monthly returns from Fama and French (1993) mimicking portfolios, Carhart (1997) momentum factor and Pastor and Stambaugh (2003) liquidity factor. Returns and alphas are in annual percent, t-statistics are shown below the coefficient estimates. In Panel A, "L/S" is the annual average return of a zero cost portfolio that buys a portfolio of connected purchases and sells short a portfolio of non-connected purchases; "L/S (Pickups)" restricts the definition of purchases to only first-time purchases ("pickups) of a stock, and equals the annual average return of a zero cost portfolio that buys a portfolio of connected pickups and sells short a portfolio of non-connected pickups. In Panel B, "L/S" is the annual average return of a zero cost portfolio that buys a portfolio of non-connected sells and sells short a portfolio of connected sells; "L/S (PminS)" is the annual average return of a zero cost portfolio that buys a portfolio of connected purchases and sells short a portfolio of connected sells. t-statistics are shown below the coefficient estimates, and 5\% statistical significance is indicated in bold.

\begin{tabular}{|c|c|c|c|c|c|c|c|c|c|}
\hline Panel A: Purchases & \multicolumn{3}{|c|}{ Raw returns } & \multicolumn{3}{|c|}{ DGTW-adjusted returns } & \multicolumn{3}{|c|}{ 5-factor alpha } \\
\hline All purchases & $\begin{array}{l}12.06 \\
(2.56)\end{array}$ & & & $\begin{array}{c}0.31 \\
(0.41)\end{array}$ & & & $\begin{array}{l}-0.58 \\
(1.12)\end{array}$ & & \\
\hline \multirow[t]{2}{*}{ Not connected purchases } & $\begin{array}{l}11.97 \\
(2.55)\end{array}$ & & & $\begin{array}{c}0.27 \\
(0.37)\end{array}$ & & & $\begin{array}{l}-0.67 \\
(1.26)\end{array}$ & & \\
\hline & $\begin{array}{l}\text { Connected } \\
\text { purchases }\end{array}$ & $\mathrm{L} / \mathrm{S}$ & $\begin{array}{c}\mathrm{L} / \mathrm{S} \\
\text { (Pickups) }\end{array}$ & $\begin{array}{l}\text { Connected } \\
\text { purchases }\end{array}$ & $\mathrm{L} / \mathrm{S}$ & $\begin{array}{c}\mathrm{L} / \mathrm{S} \\
\text { (Pickups) }\end{array}$ & $\begin{array}{l}\text { Connected } \\
\text { purchases }\end{array}$ & $\mathrm{L} / \mathrm{S}$ & $\begin{array}{c}\mathrm{L} / \mathrm{S} \\
\text { (Pickups) }\end{array}$ \\
\hline $\begin{array}{l}\text { CONNECTED1 } \\
\text { Same School }\end{array}$ & $\begin{array}{l}14.66 \\
(2.85)\end{array}$ & $\begin{array}{c}2.69 \\
(2.27)\end{array}$ & $\begin{array}{c}6.49 \\
(4.12)\end{array}$ & $\begin{array}{c}1.52 \\
(1.69)\end{array}$ & $\begin{array}{c}1.24 \\
(1.62)\end{array}$ & $\begin{array}{l}4.41 \\
(3.50)\end{array}$ & $\begin{array}{l}1.29 \\
(1.70)\end{array}$ & $\begin{array}{l}1.96 \\
(2.91)\end{array}$ & $\begin{array}{c}5.03 \\
(4.29)\end{array}$ \\
\hline $\begin{array}{l}\text { CONNECTED2 } \\
\text { Same School, same degree }\end{array}$ & $\begin{array}{l}15.58 \\
(3.15)\end{array}$ & $\begin{array}{c}3.62 \\
(3.08)\end{array}$ & $\begin{array}{c}5.91 \\
(3.35)\end{array}$ & $\begin{array}{c}2.30 \\
(2.25)\end{array}$ & $\begin{array}{c}2.03 \\
(2.54)\end{array}$ & $\begin{array}{c}4.98 \\
(5.48)\end{array}$ & $\begin{array}{l}1.82 \\
(2.01)\end{array}$ & $\begin{array}{l}2.49 \\
(2.94)\end{array}$ & $\begin{array}{c}5.73 \\
(3.90)\end{array}$ \\
\hline $\begin{array}{l}\text { CONNECTED3 } \\
\text { Same School, year overlap }\end{array}$ & $\begin{array}{l}19.64 \\
(3.59)\end{array}$ & $\begin{array}{c}7.68 \\
(5.32)\end{array}$ & $\begin{array}{c}2.80 \\
(0.55)\end{array}$ & $\begin{array}{c}5.88 \\
(3.77)\end{array}$ & $\begin{array}{c}5.61 \\
(5.39)\end{array}$ & $\begin{array}{l}1.95 \\
(0.48)\end{array}$ & $\begin{array}{c}4.96 \\
(3.16)\end{array}$ & $\begin{array}{c}5.63 \\
(3.72)\end{array}$ & $\begin{array}{c}3.56 \\
(1.08)\end{array}$ \\
\hline $\begin{array}{l}\text { CONNECTED4 } \\
\text { Same School, same degree, year overlap }\end{array}$ & $\begin{array}{l}21.01 \\
(3.62)\end{array}$ & $\begin{array}{c}9.04 \\
(3.65)\end{array}$ & $\begin{array}{c}4.01 \\
(0.62)\end{array}$ & $\begin{array}{c}6.78 \\
(3.53)\end{array}$ & $\begin{array}{c}6.50 \\
(3.94)\end{array}$ & $\begin{array}{c}2.26 \\
(0.53)\end{array}$ & $\begin{array}{c}6.34 \\
(2.92)\end{array}$ & $\begin{array}{c}7.01 \\
(3.31)\end{array}$ & $\begin{array}{c}7.49 \\
(1.69)\end{array}$ \\
\hline
\end{tabular}

The Small World of Investing - Page 39 
Table VII (continued): Connected holdings, purchases and sells, abnormal returns 1990 - 2006

\begin{tabular}{|c|c|c|c|c|c|c|c|c|c|}
\hline Panel B: Sells & \multicolumn{3}{|c|}{ Raw returns } & \multicolumn{3}{|c|}{ DGTW-adjusted returns } & \multicolumn{3}{|c|}{ 5-factor alpha } \\
\hline All sells & $\begin{array}{l}11.28 \\
(2.62)\end{array}$ & & & $\begin{array}{c}0.61 \\
(1.61)\end{array}$ & & & $\begin{array}{l}1.55 \\
(2.52)\end{array}$ & & \\
\hline \multirow[t]{2}{*}{ Not connected sells (NCS) } & $\begin{array}{l}11.10 \\
(2.60)\end{array}$ & & & $\begin{array}{c}0.54 \\
(1.30)\end{array}$ & & & $\begin{array}{c}1.44 \\
(2.27)\end{array}$ & & \\
\hline & $\begin{array}{l}\text { Connected } \\
\text { sells }\end{array}$ & $\mathrm{L} / \mathrm{S}$ & $\begin{array}{c}\mathrm{L} / \mathrm{S} \\
(\mathrm{PminS})\end{array}$ & $\begin{array}{l}\text { Connected } \\
\text { sells }\end{array}$ & $\mathrm{L} / \mathrm{S}$ & $\begin{array}{c}\mathrm{L} / \mathrm{S} \\
(\mathrm{PminS})\end{array}$ & $\begin{array}{l}\text { Connected } \\
\text { sells }\end{array}$ & $\mathrm{L} / \mathrm{S}$ & $\begin{array}{c}\mathrm{L} / \mathrm{S} \\
(\mathrm{PminS})\end{array}$ \\
\hline $\begin{array}{l}\text { CONNECTED1 } \\
\text { Same School }\end{array}$ & $\begin{array}{l}15.17 \\
(3.32)\end{array}$ & $\begin{array}{l}-4.07 \\
(3.33)\end{array}$ & $\begin{array}{l}-0.51 \\
(0.35)\end{array}$ & $\begin{array}{c}2.72 \\
(3.06)\end{array}$ & $\begin{array}{l}-2.18 \\
(2.51)\end{array}$ & $\begin{array}{l}-1.20 \\
(1.37)\end{array}$ & $\begin{array}{c}4.09 \\
(4.32)\end{array}$ & $\begin{array}{l}-2.66 \\
(2.89)\end{array}$ & $\begin{array}{l}-2.81 \\
(3.14)\end{array}$ \\
\hline $\begin{array}{l}\text { CONNECTED2 } \\
\text { Same School, same degree }\end{array}$ & $\begin{array}{l}15.19 \\
(3.09)\end{array}$ & $\begin{array}{l}-4.09 \\
(3.04)\end{array}$ & $\begin{array}{c}0.39 \\
(0.24)\end{array}$ & $\begin{array}{c}2.70 \\
(2.59)\end{array}$ & $\begin{array}{l}-2.16 \\
(1.96)\end{array}$ & $\begin{array}{l}-0.40 \\
(0.36)\end{array}$ & $\begin{array}{c}3.86 \\
(3.51)\end{array}$ & $\begin{array}{l}-2.42 \\
(2.19)\end{array}$ & $\begin{array}{l}-2.04 \\
(1.94)\end{array}$ \\
\hline $\begin{array}{l}\text { CONNECTED3 } \\
\text { Same School, year overlap }\end{array}$ & $\begin{array}{l}15.93 \\
(3.03)\end{array}$ & $\begin{array}{l}-4.83 \\
(2.06)\end{array}$ & $\begin{array}{c}3.71 \\
(1.54)\end{array}$ & $\begin{array}{c}3.07 \\
(1.75)\end{array}$ & $\begin{array}{l}-2.53 \\
(1.35)\end{array}$ & $\begin{array}{c}2.81 \\
(1.46)\end{array}$ & $\begin{array}{c}4.79 \\
(2.37)\end{array}$ & $\begin{array}{l}-3.35 \\
(1.71)\end{array}$ & $\begin{array}{c}0.17 \\
(0.07)\end{array}$ \\
\hline $\begin{array}{l}\text { CONNECTED } 4 \\
\text { Same School, same degree, year overlap }\end{array}$ & $\begin{array}{l}15.44 \\
(3.54)\end{array}$ & $\begin{array}{c}4.35 \\
(1.61)\end{array}$ & $\begin{array}{c}5.57 \\
(1.43)\end{array}$ & $\begin{array}{c}3.26 \\
(1.29)\end{array}$ & $\begin{array}{l}-2.72 \\
(1.07)\end{array}$ & $\begin{array}{c}3.52 \\
(1.13)\end{array}$ & $\begin{array}{c}4.68 \\
(2.03)\end{array}$ & $\begin{array}{l}-3.24 \\
(1.44)\end{array}$ & $\begin{array}{c}1.66 \\
(0.60)\end{array}$ \\
\hline
\end{tabular}




\section{Table VIII: Returns around corporate news announcements}

This table shows calendar time portfolio returns. At the beginning of every calendar quarter stocks in each mutual fund portfolio (based on the most recent SEC filing) are assigned to one of two portfolios (connected and non-connected). For each individual stock, we split monthly stock returns into returns on earnings announcements, "earnings announcements" defined as returns in calendar months with scheduled quarterly earnings releases, "other headlines" defined as returns in calendar months with at least 1 news announcement on the Dow Jones Newswires and no scheduled earnings announcements, and "no news returns" defined as returns in calendar months with neither news announcements on the Dow Jones newswires nor scheduled quarterly earnings releases. We compute monthly returns on connected and nonconnected holdings between reports based on the assumption that funds do not change their holdings between reports. Portfolios are rebalanced every calendar quarter and within a given fund portfolio, stocks are value weighted by the fund's dollar holdings. Finally, we compute value weighted calendar time portfolios by averaging across funds, weighting funds' portfolios by the total net asset value at the end of the previous quarter. This table includes all available stocks and all available funds. Panel A reports the distribution of the news events in the period 1990 to 2006 . In panel B we report average return of a zero cost portfolio that holds the portfolio of connected stocks and sells short the portfolio of nonconnected stocks. Columns 3 to 5 test the null hypothesis that the difference in returns between the connected and the non-connected portfolio on news (no-news) is equal to zero. Columns 5 to 7 test the null hypothesis that the difference in returns between the connected and the non-connected portfolio on news (no-news) is equal to the difference in returns between two random portfolios with the same average return. To compute simulation-adjusted return we bootstrap with replacement 100,000 random portfolios iterating the following procedure: at the beginning of every calendar quarter we sample a random portfolio of 500 CRSP stocks. Stocks are value weighted within a given portfolio and portfolios are rebalanced quarterly. Simulation-adjusted returns are defined as raw returns minus the average return of random portfolios in the same average return quintile. Returns are in annual percent, t-statistics are shown below the coefficient estimates, and $5 \%$ statistical significance is indicated in bold.

\begin{tabular}{|c|c|c|c|c|c|c|}
\hline \multicolumn{2}{|c|}{ Panel A: distribution of headlines news } & No news & \multicolumn{4}{|l|}{ news } \\
\hline \multirow{2}{*}{\multicolumn{2}{|c|}{$\begin{array}{l}\text { Percent of CRSP monthly return, } \% \text { of firms } \\
\text { Percent of CRSP monthly return, } \% \text { of ME }\end{array}$}} & 0.59 & 0.41 & \multirow{2}{*}{\multicolumn{2}{|c|}{$\begin{array}{l}\text { \# of news events } \\
\text { Average \# of news per year }\end{array}$}} & $2,681,914$ \\
\hline & & 0.55 & 0.45 & & & 157,981 \\
\hline \multirow{2}{*}{$\begin{array}{l}\text { Panel B: Connected minus } \\
\text { non-connected }\end{array}$} & \multicolumn{3}{|c|}{ L/S Returns } & \multicolumn{3}{|c|}{ L/S Simulation-adjusted returns } \\
\hline & No news & $\begin{array}{l}\text { Earnings } \\
\text { announce } \\
\text { ments }\end{array}$ & $\begin{array}{c}\text { Other } \\
\text { headlines }\end{array}$ & No news & $\begin{array}{l}\text { Earnings } \\
\text { announce } \\
\text { ments }\end{array}$ & $\begin{array}{l}\text { Other } \\
\text { headlines }\end{array}$ \\
\hline $\begin{array}{l}\text { CONNECTED1 } \\
\text { Same School }\end{array}$ & $\begin{array}{l}-0.02 \\
(-0.03)\end{array}$ & $\begin{array}{l}1.36 \\
(2.44)\end{array}$ & $\begin{array}{l}1.70 \\
(2.77)\end{array}$ & $\begin{array}{l}-0.46 \\
(-0.69)\end{array}$ & $\begin{array}{c}0.39 \\
(0.66)\end{array}$ & $\begin{array}{c}0.83 \\
(1.35)\end{array}$ \\
\hline $\begin{array}{l}\text { CONNECTED2 } \\
\text { Same School, same degree }\end{array}$ & $\begin{array}{c}0.29 \\
(-0.43)\end{array}$ & $\begin{array}{c}1.03 \\
(1.89)\end{array}$ & $\begin{array}{c}2.39 \\
(3.42)\end{array}$ & $\begin{array}{l}-0.14 \\
(-0.21)\end{array}$ & $\begin{array}{c}0.05 \\
(0.10)\end{array}$ & $\begin{array}{l}1.53 \\
(2.19)\end{array}$ \\
\hline $\begin{array}{l}\text { CONNECTED3 } \\
\text { Same School, year overlap }\end{array}$ & $\begin{array}{l}-0.18 \\
(0.27)\end{array}$ & $\begin{array}{c}4.05 \\
(3.67)\end{array}$ & $\begin{array}{c}2.99 \\
(3.14)\end{array}$ & $\begin{array}{l}-0.61 \\
(-0.92)\end{array}$ & $\begin{array}{c}3.08 \\
(2.79)\end{array}$ & $\begin{array}{c}2.13 \\
(2.24)\end{array}$ \\
\hline $\begin{array}{l}\text { CONNECTED4 } \\
\text { Same School, same degree, year overlap }\end{array}$ & $\begin{array}{c}0.09 \\
(0.07)\end{array}$ & $\begin{array}{c}3.69 \\
(3.06)\end{array}$ & $\begin{array}{l}4.58 \\
(3.07)\end{array}$ & $\begin{array}{l}-0.34 \\
(-0.34)\end{array}$ & $\begin{array}{c}2.72 \\
(2.25)\end{array}$ & $\begin{array}{c}4.60 \\
(3.09)\end{array}$ \\
\hline
\end{tabular}

The Small World of Investing - Page 41 


\section{Table IX: Robustness checks}

This table shows calendar time portfolio returns. We report the annual average return of a zero cost portfolio that holds the portfolio of connected stocks and sells short the portfolio of non-connected stocks. Connected companies are defined as firms where at least a senior official (CEO, CFO or Chairman) received any degree from the same institution as the fund's portfolio manager (CONNECTED1), received the same degree from the same institution as the fund's portfolio manager (CONNECTED2), received any degree from the same institution as the fund's portfolio manager and overlapped with the portfolio manager during the pursuit of the degree (CONNECTED3) or received the same degree from the same institution as the fund's portfolio manager, and overlapped with the portfolio manager during the pursuit of the degree (CONNECTED4). Panel A reports results by sub-period and firm characteristics. Panel B reports results by fund characteristics. Panel C reports results by institutions. School adjusted returns are defined as raw returns minus the value weighted average of a portfolio of all firms where at least a senior official (CEO, CFO or Chairman) received a degree from the same institution. "top 5 most connected" are academic institutions, ranked by the average number of connected firms (portfolio managers) over the period 1990 to 2006.

\begin{tabular}{|c|c|c|c|c|}
\hline Panel A: sub periods and size & CONNECTED1 & CONNECTED2 & CONNECTED3 & CONNECTED4 \\
\hline $\begin{array}{l}\text { Large cap stocks } \\
\text { Above NYSE median }\end{array}$ & $\begin{array}{l}3.48 \\
(2.85)\end{array}$ & $\begin{array}{c}4.20 \\
(3.54)\end{array}$ & $\begin{array}{c}7.17 \\
(4.70)\end{array}$ & $\begin{array}{c}8.47 \\
(3.76)\end{array}$ \\
\hline $\begin{array}{l}\text { Small cap stocks } \\
\text { Below NYSE median }\end{array}$ & $\begin{array}{c}6.58 \\
(2.16)\end{array}$ & $\begin{array}{l}10.65 \\
(2.04)\end{array}$ & $\begin{array}{l}21.59 \\
(2.19)\end{array}$ & $\begin{array}{l}15.72 \\
(1.89)\end{array}$ \\
\hline $1990-1998$ & $\begin{array}{c}5.16 \\
(3.48)\end{array}$ & $\begin{array}{l}5.37 \\
(3.83)\end{array}$ & $\begin{array}{c}7.71 \\
(3.96)\end{array}$ & $\begin{array}{l}8.07 \\
(2.35)\end{array}$ \\
\hline $1997-2006$ & $\begin{array}{l}4.38 \\
(2.86)\end{array}$ & $\begin{array}{c}4.91 \\
(3.68)\end{array}$ & $\begin{array}{c}8.76 \\
(4.31)\end{array}$ & $\begin{array}{c}9.51 \\
(2.80)\end{array}$ \\
\hline Pre-Reg FD & $\begin{array}{c}4.64 \\
(3.29)\end{array}$ & $\begin{array}{c}5.48 \\
(4.10)\end{array}$ & $\begin{array}{c}9.22 \\
(4.86)\end{array}$ & $\begin{array}{c}9.76 \\
(3.17)\end{array}$ \\
\hline Post-Reg FD & $\begin{array}{l}4.40 \\
(3.36)\end{array}$ & $\begin{array}{c}5.33 \\
(4.34)\end{array}$ & $\begin{array}{l}8.74 \\
(4.87)\end{array}$ & $\begin{array}{c}9.59 \\
(3.40)\end{array}$ \\
\hline \multicolumn{5}{|l|}{ Panel B: fund characteristics } \\
\hline Aggressive growth funds & $\begin{array}{l}3.52 \\
(2.07)\end{array}$ & $\begin{array}{l}4.24 \\
(3.82)\end{array}$ & $\begin{array}{c}6.41 \\
(2.66)\end{array}$ & $\begin{array}{l}7.66 \\
(2.02)\end{array}$ \\
\hline Growth funds & $\begin{array}{c}3.08 \\
(1.77)\end{array}$ & $\begin{array}{c}4.03 \\
(3.38)\end{array}$ & $\begin{array}{c}5.73 \\
(3.39)\end{array}$ & $\begin{array}{l}6.91 \\
(2.70)\end{array}$ \\
\hline Growth and income funds & $\begin{array}{c}1.74 \\
(1.02)\end{array}$ & $\begin{array}{c}3.24 \\
(2.27)\end{array}$ & $\begin{array}{c}5.77 \\
(2.71)\end{array}$ & $\begin{array}{l}8.69 \\
(3.21)\end{array}$ \\
\hline $\begin{array}{l}\text { Large cap funds } \\
\text { Above median }\end{array}$ & $\begin{array}{l}3.05 \\
(2.72)\end{array}$ & $\begin{array}{c}3.72 \\
(3.24)\end{array}$ & $\begin{array}{c}6.94 \\
(4.67)\end{array}$ & $\begin{array}{l}8.43 \\
(3.82)\end{array}$ \\
\hline $\begin{array}{l}\text { Small cap funds } \\
\text { Below median }\end{array}$ & $\begin{array}{l}2.95 \\
(2.85)\end{array}$ & $\begin{array}{c}3.73 \\
(2.67)\end{array}$ & $\begin{array}{l}2.81 \\
(1.40)\end{array}$ & $\begin{array}{l}4.59 \\
(2.11)\end{array}$ \\
\hline Single portfolio manager & $\begin{array}{l}3.01 \\
(2.37)\end{array}$ & $\begin{array}{c}4.02 \\
(3.35)\end{array}$ & $\begin{array}{l}5.57 \\
(3.85)\end{array}$ & $\begin{array}{c}6.71 \\
(3.29)\end{array}$ \\
\hline Multiple portfolio manager & $\begin{array}{l}3.18 \\
(3.31)\end{array}$ & $\begin{array}{l}3.03 \\
(2.21)\end{array}$ & $\begin{array}{l}9.21 \\
(2.51)\end{array}$ & $\begin{array}{l}12.56 \\
(2.18)\end{array}$ \\
\hline $\begin{array}{l}\text { Local holdings } \\
<100 \mathrm{Km}, 1994-2006\end{array}$ & $\begin{array}{c}2.77 \\
(2.77)\end{array}$ & $\begin{array}{c}4.41 \\
(3.27)\end{array}$ & $\begin{array}{c}7.55 \\
(4.09)\end{array}$ & $\begin{array}{l}10.03 \\
(4.17)\end{array}$ \\
\hline $\begin{array}{l}\text { Distant local holdings } \\
>100 \mathrm{Km}, 1994-2006\end{array}$ & $\begin{array}{c}2.26 \\
(2.19)\end{array}$ & $\begin{array}{l}3.80 \\
(2.76)\end{array}$ & $\begin{array}{c}7.21 \\
(4.14)\end{array}$ & $\begin{array}{c}9.30 \\
(4.23)\end{array}$ \\
\hline \multicolumn{5}{|l|}{ Panel B: institutions } \\
\hline Only non-ivy league & $\begin{array}{c}4.63 \\
(2.67)\end{array}$ & $\begin{array}{c}4.81 \\
(3.08)\end{array}$ & $\begin{array}{c}8.13 \\
(4.08)\end{array}$ & $\begin{array}{c}9.68 \\
(3.18)\end{array}$ \\
\hline Only ivy league & $\begin{array}{c}4.12 \\
(4.86)\end{array}$ & $\begin{array}{c}4.65 \\
(3.30)\end{array}$ & $\begin{array}{c}2.00 \\
(0.89)\end{array}$ & $\begin{array}{c}3.77 \\
(1.27)\end{array}$ \\
\hline School-adjusted return & $\begin{array}{c}1.25 \\
(1.94)\end{array}$ & $\begin{array}{l}1.86 \\
(2.41)\end{array}$ & $\begin{array}{c}4.38 \\
(4.70)\end{array}$ & $\begin{array}{c}5.65 \\
(3.24)\end{array}$ \\
\hline Top 5 most connected & $\begin{array}{l}2.88 \\
(2.46)\end{array}$ & $\begin{array}{c}3.79 \\
(2.72)\end{array}$ & $\begin{array}{c}6.42 \\
(3.89)\end{array}$ & $\begin{array}{c}7.72 \\
(3.56)\end{array}$ \\
\hline Not Top 5 most connected & $\begin{array}{c}3.09 \\
(2.78)\end{array}$ & $\begin{array}{c}3.77 \\
(3.28)\end{array}$ & $\begin{array}{c}6.88 \\
(4.62)\end{array}$ & $\begin{array}{c}8.16 \\
(3.66)\end{array}$ \\
\hline
\end{tabular}

The Small World of Investing - Page 42 


\section{Table X: Changes in portfolio weights around changes in portfolio managers}

This table reports OLS regressions of changes in mutual funds' portfolio weights around changes in educational connections. In this table, connected companies are defined as firms where at least a senior official (CEO, CFO or Chairman) received the same degree from the same institution as the fund's portfolio manager, and overlapped with the portfolio manager during the pursuit of the degree. This figure included the universe of mutual funds managed by a single portfolio manager. A manager change represents a replacement of the fund's portfolio manager where the new portfolio manager and the prior portfolio manager never received a degree from the same academic institution. The dependent variable is the average fund portfolio weight in the stock in the year following manager change (time zero), minus the average fund holding in the year before manager change. New Manager's Stock is a categorical variable equal to 1 for any stock held in the new manager's portfolio, while New Manager's Connected Stock is a categorical variable equal to 1 for any stock held that is connected to the new manager. Old Manager's Stock and Old Manager's Connected Stock are defined equivalently. The control variables included where indicated are: \%STYLE, the percentage of the fund's total net assets invested in the style corresponding to the stock being considered (style is calculated as in DGTW (1997)), ME, BM and R12 which are percentiles of market value of equity, book to market, and past 12 month return. Quarter fixed effects are included in each regression, and firm, fund's investment objective code (IOC), and fund fixed effects are included where indicated. Weights are in basis points; standard errors are adjusted for clustering at the quarter level, and $t$-statistics are reported in brackets below the coefficient estimates. $5 \%$ statistical significance is indicated in bold.

\begin{tabular}{lccccc}
\hline OLS regression: Weight Change & 1 & 2 & 3 & 4 & 5 \\
Following Manager Turnover & & & & & \\
Constant & -7.31 & -17.87 & -16.28 & 2.97 & -31.02 \\
& $(-1.84)$ & $(-3.41)$ & $(-1.79)$ & $(0.49)$ & $(-1.60)$ \\
New Manager's Stock & 55.15 & 53.30 & 53.48 & 53.42 & 56.10 \\
& $(18.2)$ & $(17.1)$ & $(18.8)$ & $(17.0)$ & $(16.0)$ \\
New Manager's Connected Stock & 45.98 & 48.48 & 43.35 & 48.54 & 46.31 \\
& $(2.49)$ & $(2.34)$ & $(2.12)$ & $(2.34)$ & $(2.18)$ \\
Old Manager's Stock & -58.03 & -65.82 & -69.08 & -65.79 & -71.48 \\
& $(-9.88)$ & $(-11.7)$ & $(-13.8)$ & $(-11.7)$ & $(-11.1)$ \\
Old Manager's Connected Stock & -4.77 & -3.11 & -7.66 & -3.16 & -2.57 \\
& $(-0.38)$ & $(-0.27)$ & $(-0.65)$ & $(-0.27)$ & $(-0.23)$ \\
Controls & No & Yes & Yes & Yes & Yes \\
Fixed effect & Quarter & Quarter & Quarter & Quarter & Quarter \\
Fixed effect & & & Firm & IOC & Fund \\
R2 & 0.19 & 0.21 & 0.25 & 0.21 & 0.27 \\
\hline
\end{tabular}




\section{Table XI: Fund manager behavior}

Panel A reports the average fraction of fund holdings invested in connected securities, the average fraction of connected securities in the market portfolio and the difference between them. Fama MacBeth t-statistics are reported below the coefficient estimates. Panel B reports average Sharpe ratios of individual funds. For each fund manager $j$, we compute Sharpe ratios (SR) in connected securities and report the averages across funds:

$$
\overline{S R}=(1 / n) \sum_{j} S R_{j}
$$

Column 3 of panel B reports the \% of funds with in-sample increase in SR. For each fund manager $j$ we run a time series regression of the fund's monthly return in connected securities (CONNRET) on the funds total return $(R E T)$ :

$$
\operatorname{CONNRET}_{j, t}=\alpha_{j}+\beta_{j} R E T_{j, t}+\varepsilon_{j, t}
$$

Column 3 reports the fraction of funds where the null hypothesis $\alpha=0$ is rejected at $5 \%$ significance. Panel C reports pooled, cross-sectional OLS regressions of mutual fund manager trading activity:

$$
d w_{j, t}^{i}=a+b_{1} D W_{x j_{-}}^{i} \text { CONNECTED, } t+b_{2} Z 1+b_{3}\left(D w_{x j_{-}}^{i} \text { CONNECTED, }{ }^{*} Z 1\right)+b_{4} \operatorname{CONTROLS}_{t}^{i}+\varepsilon_{j, t}^{i}
$$

The dependent variable $\left(d w_{j, t}^{i}\right)$ is the change in the percentage holding of a stock by a given mutual fund in a given quarter. For a given portfolio manager $j$, we identify all fund managers that went to the same school as the fund manager $j$ and then sum up all their dollar holdings (excluding manager $j$ 's holdings). We then compute the change $\left(D W_{M C}\right)$ in this connected mutual fund portfolio, and include this as an explanatory variable in our regressions. We also include a dummy variable $(Z 1)$ equal to 1 if fund manager $j$ is connected to stock $i$ in quarter $t$, and an interaction term $\left(D W_{M C}{ }^{*} Z 1\right)$ that captures the extent to which fund manager $j$ 's trading behavior is related to the trading behavior of the connected mutual fund portfolio for connected stocks in particular. We compute aggregate mutual fund portfolio change $\left(D W_{A L L}\right)$, equal to the change in the mutual fund portfolio of all fund managers. The other explanatory variables are the stock is lagged market capitalization $(M E)$, stock $i$ 's lagged book-to-market ratio, and stock i's lagged quarterly return. Units are in percentage points; standard errors are adjusted for clustering at the quarter level, and $t$-statistics are reported in brackets below the coefficient estimates. $5 \%$ statistical significance is indicated in bold. 
Table XI: Fund manager behavior

(Continued)

\begin{tabular}{|c|c|c|c|c|c|c|c|c|}
\hline \multirow[b]{3}{*}{ All holdings } & \multicolumn{3}{|c|}{ Panel A: Assets connected } & \multicolumn{5}{|c|}{ Panel B: average Sharpe Ratio of individual funds } \\
\hline & $\%$ held & $\%$ market & difference & \multicolumn{2}{|c|}{$\overline{S R}$} & Difference & \multicolumn{2}{|c|}{$\begin{array}{l}\% \text { funds with in-sample } \\
\text { increase in SR }\end{array}$} \\
\hline & & & & \multicolumn{2}{|c|}{0.518} & & & \\
\hline $\begin{array}{l}\text { CONNECTED1 } \\
\text { Same School }\end{array}$ & 0.035 & 0.066 & $\begin{array}{l}-0.031 \\
(-9.68)\end{array}$ & \multicolumn{2}{|c|}{0.373} & $\begin{array}{l}-0.145 \\
(-4.57)\end{array}$ & \multicolumn{2}{|c|}{0.054} \\
\hline $\begin{array}{l}\text { CONNECTED2 } \\
\text { Same School, same degree }\end{array}$ & 0.019 & 0.040 & $\begin{array}{l}-0.021 \\
(-9.64)\end{array}$ & \multicolumn{2}{|c|}{0.406} & $\begin{array}{l}-0.111 \\
(-2.28)\end{array}$ & \multicolumn{2}{|c|}{0.052} \\
\hline $\begin{array}{l}\text { CONNECTED3 } \\
\text { Same School, year overlap }\end{array}$ & 0.003 & 0.008 & $\begin{array}{l}-0.005 \\
(-10.06)\end{array}$ & \multicolumn{2}{|c|}{0.391} & $\begin{array}{l}-0.126 \\
(-4.35)\end{array}$ & \multicolumn{2}{|c|}{0.029} \\
\hline $\begin{array}{l}\text { CONNECTED4 } \\
\text { Same School, same degree, year overlap }\end{array}$ & 0.001 & 0.004 & $\begin{array}{l}-0.003 \\
(-10.58)\end{array}$ & \multicolumn{2}{|c|}{0.389} & $\begin{array}{l}-0.129 \\
(-2.61)\end{array}$ & \multicolumn{2}{|c|}{0.019} \\
\hline Panel C: Herding & \multicolumn{8}{|c|}{ Independent Variables } \\
\hline LHS $=d w$ & $D W_{M C}$ & $D W_{M C}{ }^{*} Z 1$ & $Z 1$ & $D W_{A L L}$ & $D W_{A L L} * Z 1$ & $\ln \left(\mathrm{ME}_{\mathrm{t}-1}\right)$ & $\ln \left(\mathrm{B} / \mathrm{M}_{\mathrm{t}-1}\right)$ & $\mathrm{RET}_{\mathrm{t}-1}$ \\
\hline Model 1 & $\begin{array}{c}0.674 \\
(11.32)\end{array}$ & & & & & & & \\
\hline Model 2 & $\begin{array}{c}0.628 \\
(10.32)\end{array}$ & & & $\begin{array}{l}0.715 \\
(3.43)\end{array}$ & & & & \\
\hline Model 3 & $\begin{array}{l}0.613 \\
(9.86)\end{array}$ & $\begin{array}{l}0.698 \\
(3.29)\end{array}$ & $\begin{array}{c}-0.000 \\
(0.45)\end{array}$ & & & & & \\
\hline Model 4 & $\begin{array}{l}0.577 \\
(9.13)\end{array}$ & $\begin{array}{l}0.645 \\
(3.01)\end{array}$ & $\begin{array}{c}-0.000 \\
(0.50)\end{array}$ & $\begin{array}{l}0.658 \\
(3.14)\end{array}$ & $\begin{array}{l}-2.752 \\
(-0.39)\end{array}$ & & & \\
\hline Model 5 & $\begin{array}{l}0.570 \\
(8.98)\end{array}$ & $\begin{array}{l}0.648 \\
(3.02)\end{array}$ & $\begin{array}{c}-0.000 \\
(0.43)\end{array}$ & $\begin{array}{l}0.661 \\
(3.15)\end{array}$ & $\begin{array}{l}-2.864 \\
(-0.40)\end{array}$ & $\begin{array}{c}-0.000 \\
(0.84)\end{array}$ & $\begin{array}{c}-0.000 \\
(0.40)\end{array}$ & $\begin{array}{l}0.001 \\
(3.33)\end{array}$ \\
\hline
\end{tabular}


Figure 1: Cummins Engine, 3/1/1996 - 6/30/1998

This figure shows the stock price of Cummins Engine between 3/1/1996 and 6/30/1998.

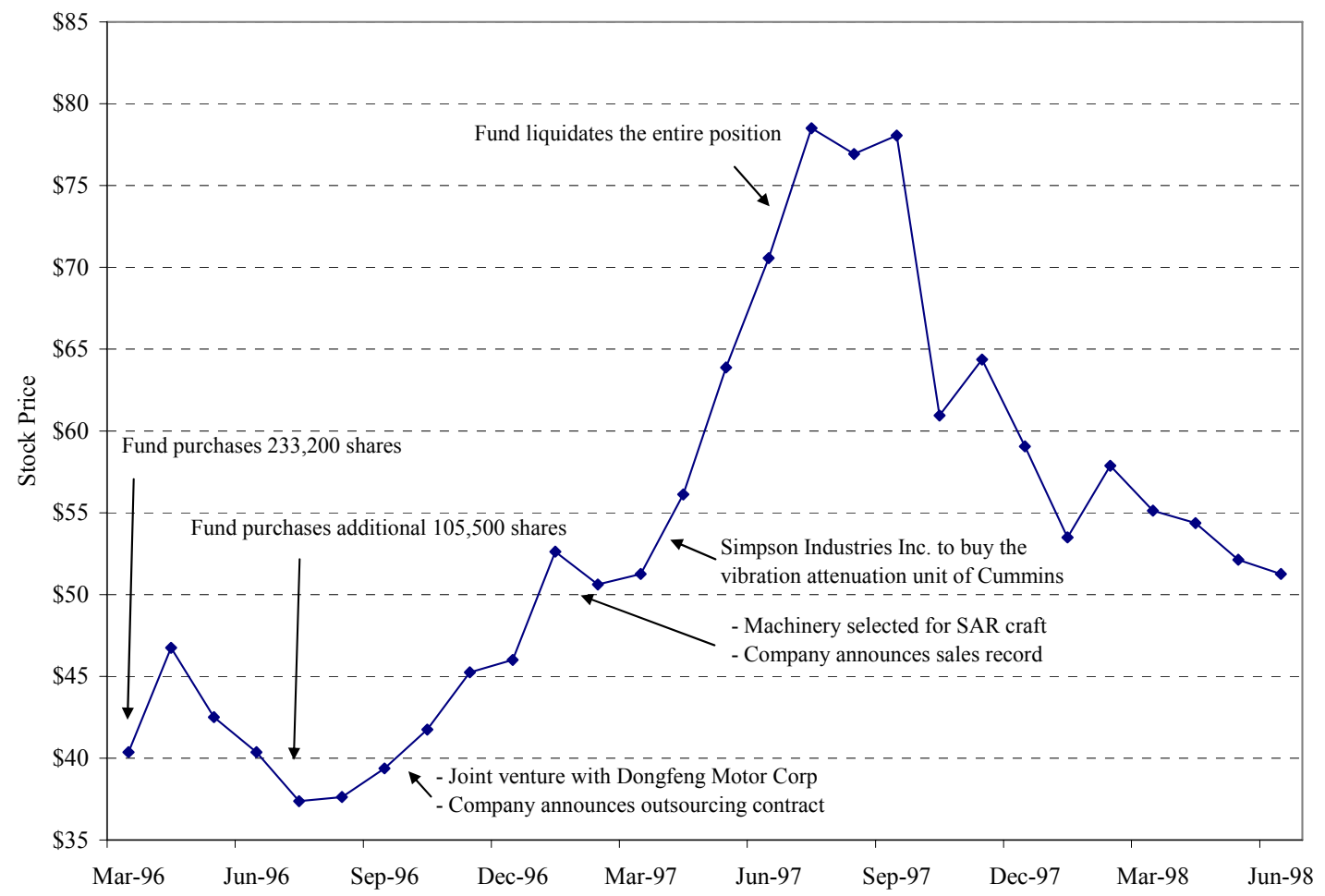

The Small World of Investing - Page 46 


\section{Figure 2: Returns on connected holdings, $1990-2006$}

This figure shows calendar time portfolio returns. At the beginning of every calendar quarter stocks in each mutual fund portfolio (based on the most recent SEC filing) are assigned to one of two portfolios (connected and non-connected). In this table, connected companies are defined as firms where at least a senior official (CEO, CFO or Chairman) received the same degree from the same institution as the fund's portfolio manager, and overlapped with the portfolio manager during the pursuit of the degree. We compute monthly returns on connected and non connected holdings between reports based on the assumption that funds did not change their holding between reports. Portfolios are rebalanced every calendar quarter and within a given fund portfolio, stocks are weighted by the fund's dollar holdings. Finally, we compute value weighted calendar time portfolios by averaging across funds, weighting individual fund portfolios by the fund's total net asset value at the end of the previous quarter. This table includes all available stocks and all available funds. We report annual returns of a zero cost portfolio that holds the portfolio of connected stocks and sells short the portfolio of non connected stocks.

L/S returns, connected minus not connected

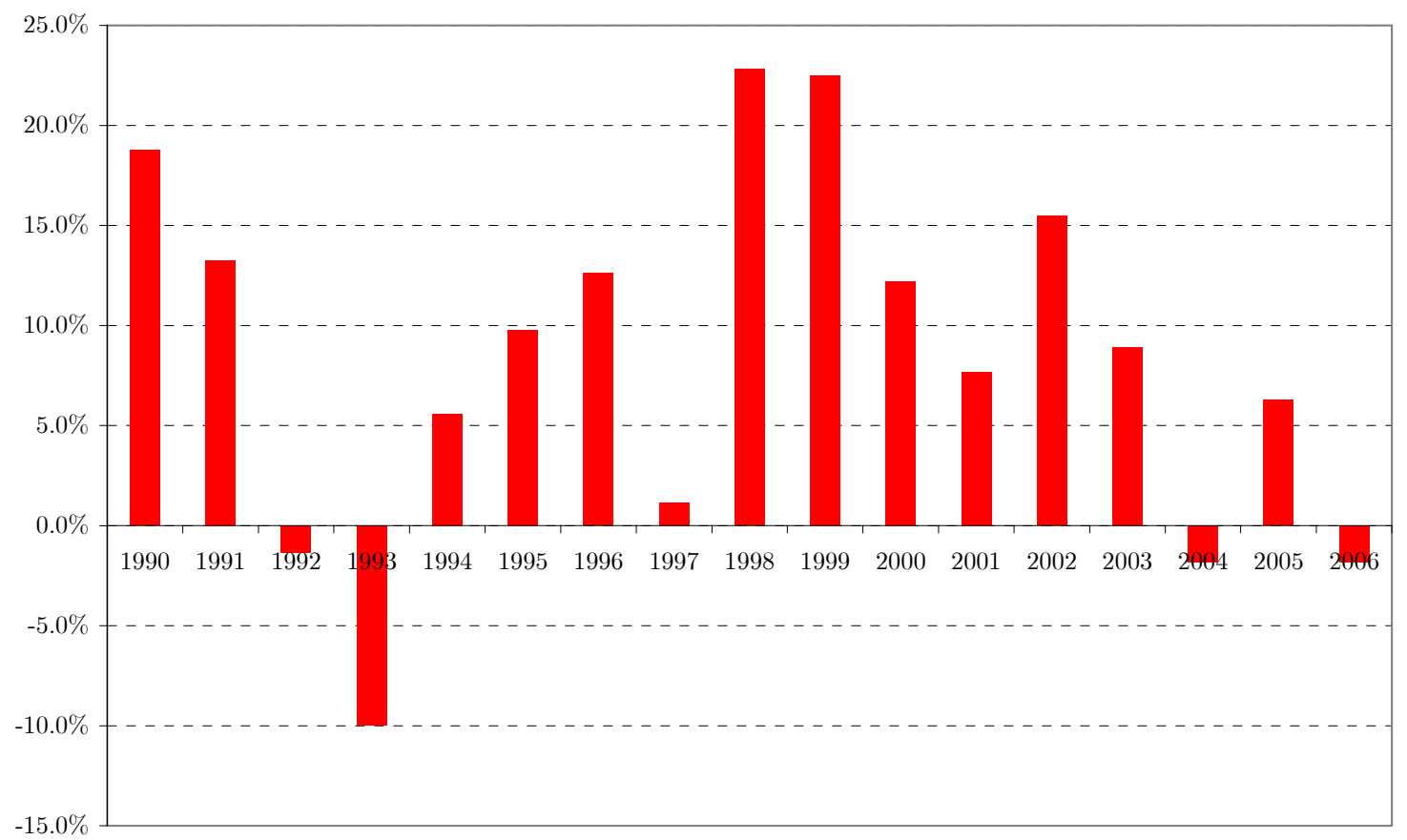




\section{Figure 3: Connected weights at manager Changes}

This figure shows the holdings of mutual funds around changes in educational connections. In this figure, connected companies are defined as firms where at least a senior official (CEO, CFO or Chairman) received the same degree from the same institution as the fund's portfolio manager, and overlapped with the portfolio manager during the pursuit of the degree. This figure included the universe of mutual funds managed by a single portfolio manager. A manager change represents a replacement of the fund's portfolio manager where the new portfolio manager and the prior portfolio manager did not receive a degree from the same academic institution. In the figure quarter -1 represents the last portfolio snapshot of the old manager and quarter +1 represents the first portfolio snapshot of the new manager. Weight is defined as percentage holding of a stock averaged over the last 2 quarters (for event quarter $<0$ ) or over the next 2 quarters (for event quarter $>0$ ). "Average weight in stocks connected to the old manager" measures the weights on stocks connected to the old manager, but not to the new manager. "Average weight in stocks connected to the new manager" measures the weights on stocks connected to the new manager, but not to the old manager. Weights are in basis points.

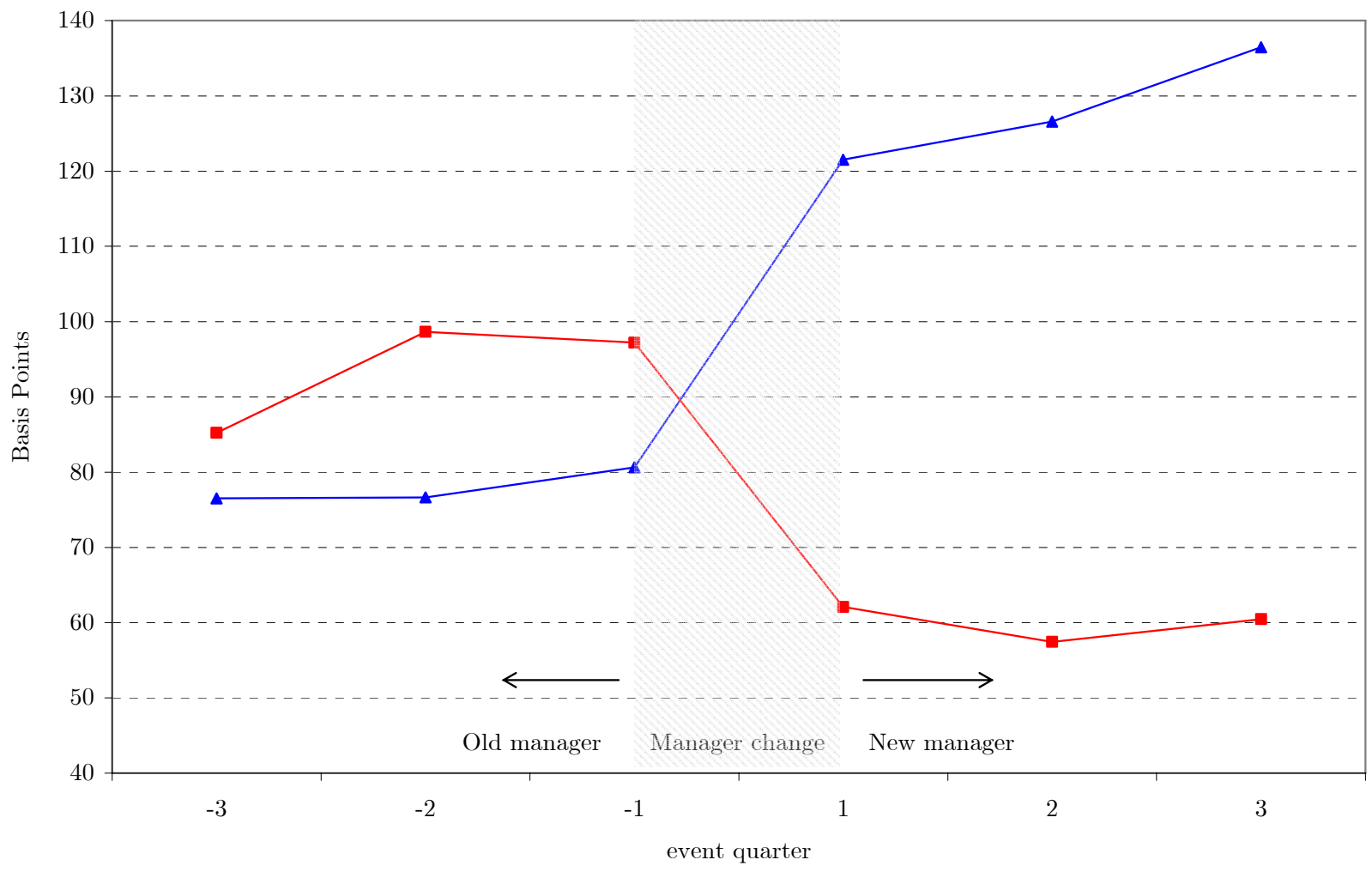

$\leftarrow$ Average weight in stocks connected to the new manager $\rightarrow$ Average weight in stocks connected to the old manager 


\section{Appendix}

\section{A. Morningstar data}

Since Morningstar only tracks active funds, we use all the historical Morningstar OnDisk and Principia CD-ROM at monthly or quarterly intervals (depending upon availability) and the Morningstar Mutual Fund Sourcebook between 1990 and 2003. Unfortunately, due to a change in Morningstar's data storage process, subsequent to 2003, most of the biographical information is no longer available on the Principia CD-ROM. We obtain the remaining data directly from Morningstar, which provided us with managers' biographical information on both active and inactive funds between 2003 and 2006. When data entries about a fund or a portfolio manager are available from multiple source dates, we use data from the most recent source date to account for data corrections in subsequent releases. Funds on Morningstar are identified by a ticker-date combination.

\section{B. Matching institutions}

The first problem in matching institutions from BoardEx and Morningstar is the situation in which there are multiple names for a given institution in both BoardEx and Morningstar. In addition, there are names that could be potentially matched to multiple institutions and the individual biography does not make it clear which institution the portfolio manager or the firm's officer attended. We match institutions with multiple names by hand. Most specialized school names are easy to match back to institution (e.g. Wharton), however if a specialized school name could match multiple institutions (e.g. SOM), we drop these observations from the sample. In addition, we match all entries given as simply state names to the University of State Name. In dealing with multiple campuses, we matched each satellite campus as a separate university (e.g. UCLA, UCSD, and UC Berkeley are treated as separate universities). If just a university name is given for a university system that has satellite campuses (e.g. Penn State for the Penn State system of schools), we assume the entry refers to the main campus. Whenever a single name is given that could apply to two educational institutions 
(e.g. Augustana could refer to Augustana College or Augustana University) and the individual biography does not make it clear which institution was attended, we drop the observations from our sample. Lastly, although we are able to match most international universities (outside US), some names refer to multiple institutions in multiple countries. We are not able to uniquely match these, and thus drop this small number of observations from the sample. Finally, we group the degrees into six categories: (i) business school (MBA), (ii) medical school, (iii) general graduate (MA or MS), (iv) $\mathrm{PhD}$, (v) law school, and (vi) general undergraduate. Most of the data on general graduate degrees or undergraduate degrees do not allow us to reliably determine the major course of study, and thus we classify them in the two broad categories of (iii) and (vi).

\section{Headline news data}

We extract headline news data from the Dow Jones newswires using the Factiva web interface. First, we use the CRSP monthly stock name file to identify all company names of CRSP firms between 1990 and 2006. We then select all the Dow Jones Newswires available on Factiva (23 total) and for each stock on the CRSP tape we extract all the news events where the firm's name (or any of the names if multiple names exist for a given stock) is mentioned in either the headline or in the lead paragraph. We restrict the search to news items in English containing at least 5 words. We exclude republished news and recurring pricing or market data. For every news item we retain the headline, the release date, the release time, the word count and the data source. The final sample includes 2,685,684 headlines for 14,084 stocks between the year 1990 and 2006 . Table A1 gives the distribution of news count by data source.

\section{Connected Boards}

The use of senior officers to define connected firms has the advantage of being simple and intuitive but it is obviously arbitrary. Table A2 reports calendar time portfolio returns on connected and non-connected stocks using an alternative definition of connected holdings that exploits the identity of the entire board of 
directors of the firm, not just the top senior officers. We define connected companies as firms where at least a 50\% of the board of directors received a degree from the same institution as the fund's portfolio manager (CONNECTED1). We further classify connected firms as CONNECTED2 if at least one member of the board of directors received the same degree from the same institution as the fund's portfolio manager, CONNECTED3 if at least one board member received any degree from the same institution as the fund's portfolio manager but overlapped with the portfolio manager during the pursuit of the degree, and CONNECTED4 if at least one board member received the same degree from the same institution as the fund's portfolio manager, and overlapped with the portfolio manager during the pursuit of the degree. Results in table A2 confirm that, even under an alternative definition of connected firms, mutual fund managers earn high returns on their connected holdings: a replicating portfolio of their connected stocks consistently outperforms a replicating portfolio of their non-connected holdings. 
Table A1: News data, $1990-2006$

\begin{tabular}{lrr}
\hline & \# of news & percent \\
Dow Jones News Service & $1,040,427$ & 38.7 \\
Professional Investor Report & 352,818 & 13.1 \\
Select Federal Filings Newswires & 305,409 & 11.4 \\
Federal Filings Newswires & 230,016 & 8.6 \\
Dow Jones News Service - Ticker & 204,971 & 7.6 \\
Other & 552,043 & 20.6 \\
All & $2,685,684$ & 100.0 \\
\hline
\end{tabular}


Table A2: Board connections, abnormal returns 1990 - 2006

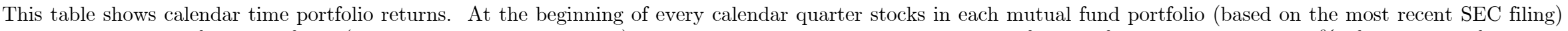

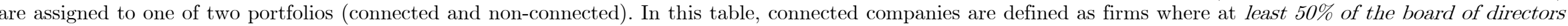

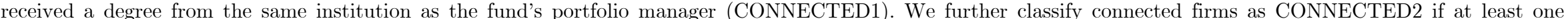

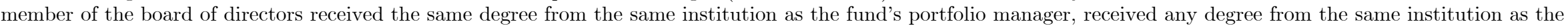

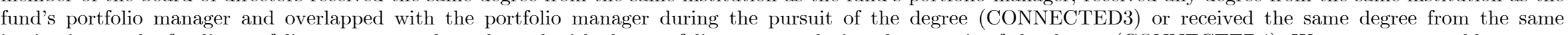
institution as the fund's portfolio manager, and overlapped with the portfolio manager during the pursuit of the degree (CONNECTED4). We compute monthly returns

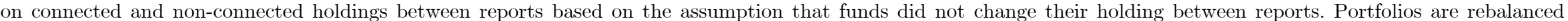

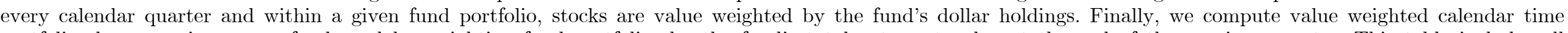

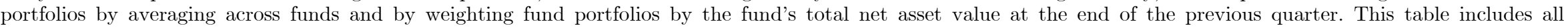

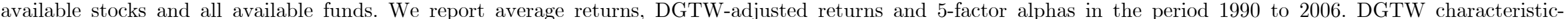

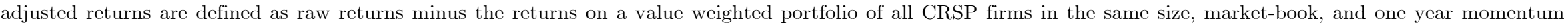

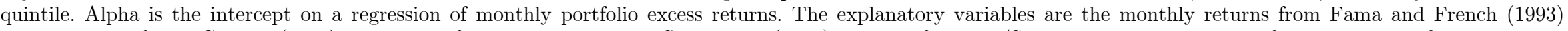

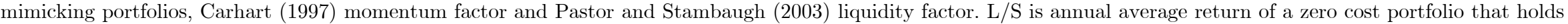

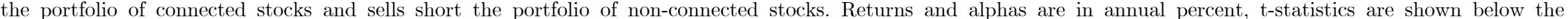
coefficient estimates, and 5\% statistical significance is indicated in bold.

\begin{tabular}{|c|c|c|c|c|c|c|}
\hline \multirow{3}{*}{$\begin{array}{l}\text { Panel A: value weighted returns } \\
\text { Not connected }\end{array}$} & \multicolumn{2}{|c|}{ Raw return } & \multicolumn{2}{|c|}{ DGTW-adjusted returns } & \multicolumn{2}{|c|}{ 5-factor alpha } \\
\hline & $\begin{array}{l}11.23 \\
(2.51)\end{array}$ & & $\begin{array}{l}-0.06 \\
(-0.13)\end{array}$ & & $\begin{array}{l}-0.57 \\
(-0.81)\end{array}$ & \\
\hline & $\begin{array}{l}\text { Connected } \\
\text { holdings }\end{array}$ & $\mathrm{L} / \mathrm{S}$ & $\begin{array}{l}\text { Connected } \\
\text { holdings }\end{array}$ & $\mathrm{L} / \mathrm{S}$ & $\begin{array}{l}\text { Connected } \\
\text { holdings }\end{array}$ & $\mathrm{L} / \mathrm{S}$ \\
\hline $\begin{array}{l}\text { CONNECTED1 } \\
>50 \% \text { Same School }\end{array}$ & $\begin{array}{l}17.32 \\
(3.15)\end{array}$ & $\begin{array}{c}6.09 \\
(2.68)\end{array}$ & $\begin{array}{l}4.26 \\
(2.78)\end{array}$ & $\begin{array}{c}4.32 \\
(2.51)\end{array}$ & $\begin{array}{c}6.04 \\
(3.10)\end{array}$ & $\begin{array}{c}6.61 \\
(3.35)\end{array}$ \\
\hline $\begin{array}{l}\text { CONNECTED } 2 \\
>50 \% \text { Same School and at least } 1 \text { same degree }\end{array}$ & $\begin{array}{l}17.05 \\
(3.03)\end{array}$ & $\begin{array}{l}5.83 \\
(2.49)\end{array}$ & $\begin{array}{c}3.72 \\
(2.44)\end{array}$ & $\begin{array}{l}3.78 \\
(2.24)\end{array}$ & $\begin{array}{c}6.44 \\
(3.23)\end{array}$ & $\begin{array}{c}7.01 \\
(3.44)\end{array}$ \\
\hline $\begin{array}{l}\text { CONNECTED } 3 \\
>50 \% \text { Same School and at east } 1 \text { year overlap }\end{array}$ & $\begin{array}{l}17.49 \\
(3.07)\end{array}$ & $\begin{array}{c}6.26 \\
(2.80)\end{array}$ & $\begin{array}{c}3.58 \\
(3.17)\end{array}$ & $\begin{array}{c}3.64 \\
(3.43)\end{array}$ & $\begin{array}{l}8.88 \\
(3.52)\end{array}$ & $\begin{array}{c}9.45 \\
(3.84)\end{array}$ \\
\hline $\begin{array}{l}\text { CONNECTED } 4 \\
>50 \% \text { Same School } \\
\text { and at least } 1 \text { same degree - year overlap }\end{array}$ & $\begin{array}{l}19.71 \\
(3.15)\end{array}$ & $\begin{array}{l}8.48 \\
(2.64)\end{array}$ & $\begin{array}{c}5.05 \\
(2.57)\end{array}$ & $\begin{array}{c}5.11 \\
(2.75)\end{array}$ & $\begin{array}{l}10.82 \\
(3.80)\end{array}$ & $\begin{array}{l}11.39 \\
(3.98)\end{array}$ \\
\hline
\end{tabular}

